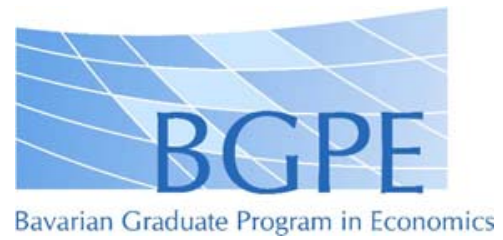

BGPE Discussion Paper

No. 19

\title{
Are twin currency and debt crisis special?
}

\author{
Christian Bauer \\ Bernhard Herz \\ Volker Karb
}

September 2006

ISSN 1863-5733

Editor: Prof. Regina T. Riphahn, Ph.D.

Friedrich-Alexander-University Erlangen-Nuremberg

(c) Christian Bauer, Bernhard Herz, Volker Karb 


\title{
Are twin currency and debt crises special?
}

\author{
Christian Bauer \\ Bernhard Herz \\ Volker Karb* \\ University of Bayreuth \\ University of Bayreuth \\ University of Bayreuth
}

September 2006

\begin{abstract}
In the literature on currency and banking crises it has become the standard procedure to distinguish pure currency crises, pure banking crises and combined (“twin”) currency and banking crises. We show theoretically and empirically that a similar differentiation should be chosen with regard to currency and debt crises. Twin currency and debt crises differ from both pure currency and pure debt crises in their determinants, course of events, and economic consequences. We find that each type of crises has a unique set of macroeconomic causes. We also identify internal contagion and selection bias effects, which may lead to biased empirical estimates if twin crises are not treated as a specific type of crises. Such a separation allows to significantly improve the efficiency of early warning systems especially for debt and twin crises.
\end{abstract}

JEL-Classification: F31, F33, F34, F41

Keywords: currency crises, debt crises, twin crises, emerging markets

\footnotetext{
* University of Bayreuth, Chair of Economic Policy (VWL I), 95440 Bayreuth, Germany. Tel.: +49-921-552913. Fax:+49-921-552949. E-mail: volker.karb@uni-bayreuth.de.
} 


\section{Introduction}

In the literature on currency and banking crises it has become the standard procedure to treat pure currency crises, pure banking crises and combined ("twin”) currency and banking crises as separate classes of crises. For example, in empirical studies the output effects and frequencies are usually analyzed separately for each of these crises. ${ }^{1}$ In contrast, in the literature on debt and currency crises such a distinction is less common- even though empirically twin debt and currency crises are at least as frequent as the more prominent twin currency and banking crises. ${ }^{2}$ Therefore, we address the following question: Should twin debt and currency crises also be regarded as a specific type of crisis, which should be analyzed separately from pure currency and pure debt crises (table 1)? Can such a classification improve the analysis of fiscal and exchange rate crises? Most importantly, does it on the empirical side improve the quality of early warning indicators and the prediction of financial crises? If debt and currency crises are interrelated due to common causes and / or direct contagion effects from one crisis to the other, an explicit consideration of these interrelations may indeed enhance the results of empirical analyses and the forecasts of early warning systems.

Table 1: Default and devaluation

\begin{tabular}{|l|c|c|}
\hline & No devaluation & Devaluation \\
\hline No default & Non-crisis & Pure currency crisis \\
\hline Default & Pure sovereign debt crisis & Twin debt and currency crisis \\
\hline
\end{tabular}

Early warning systems for financial crises have been extensively analyzed in the literature. ${ }^{3}$ However, their forecasting performance has been mixed and often been poor in the sense that indicators failed to predict crises that in fact did occur (type I errors) or that they predicted crises in cases when in fact no crisis occurred (type II errors, "false alarms"; see

\footnotetext{
${ }^{1}$ See e.g. IMF (1998), Glick and Hutchison (1999), Kaminsky and Reinhart (1999), DeLargy and Goodhart (1999), Bordo, Eichengreen, Klingebiel, and Martinez-Peria (2001), Eichengreen (2002), and Bordo and Eichengreen (2003).

${ }^{2}$ Herz and Tong (2003) analyze a developing countries sample and find that 32 percent of all debt crises in their sample are linked to currency crises, while 20 percent of the currency crises are associated with debt crises. Reinhart (2002) finds that 84 percent of the defaults in her emerging markets sample are connected with currency crises and almost half of the currency crises in the sample are related to defaults. Recent, prominent examples of simultaneous debt and currency crises include Russia (1998) and Argentina (2001). Reinhart (2002) supposes that other countries, that recently experienced balance of payments and exchange rate problems such as Mexico, South Korea, Thailand, and Turkey, would most likely have suffered from debt service difficulties as well if they had not obtained vast international rescue packages.

${ }^{3}$ For a review see Edison (2003).
} 
IMF, 2002). For example, Frankel and Rose (1996) as one of the first authors to study macroeconomic predictors of currency crises provide only a low explanatory and predictive potential: While their numbers of false alarms remains below $1 \%$, they only predict five out of 69 currency crises.

In the following we show that analyzing currency crises, debt crises, and twin crises as separate events can improve the efficiency and the predictive power of early warning systems. Our approach distinguishes between the direct and indirect effects of macroeconomic variables on these different types of crises. If for example standard analyses of debt crises identify inflation as an important crisis predictor, this may well be the case because inflation directly makes currency crises more likely, which in turn can trigger simultaneous debt crises via contagion effects. ${ }^{4}$ Thus, while inflation may in fact only be an indicator for twin debt and currency crises, traditional analyses would show that it is an indicator for pure debt as well as twin currency and debt crises, as the strong impact of inflation on twin crises is carried forward to the entire sample of debt crises.

In our sample the predictive value of macroeconomic variables is lowest for currency crises and best for twin crises. If twin crises are treated as a separate type of crisis, $36 \%$ of all currency crises, $75 \%$ of all debt crises, and $50 \%$ of all twin crises are predicted correctly, while we get $1.6 \%$ false alarms for the prediction of currency crises, $12 \%$ false alarms for the prediction of debt crises, and $0.3 \%$ false alarms for the prediction of twin currency and debt crises.

The remainder of the paper is organized as follows. Section 2 reviews theoretical aspects of the interrelations between debt and currency crises. Section 3 presents some stylized facts on the development of various key economic variables in the financial crises situations. In Section 4, we present the empirical results from GLM estimations. We also use an extensive GLM model to evaluate early warning systems for the different types of crises. Section 5 concludes.

\section{Determinants of currency and sovereign debt crises}

Currency crises and sovereign debt defaults are recurring phenomenons. Typically they are accompanied by a drop in real economic activity, which in the past was particularly

\footnotetext{
${ }^{4}$ Usually the term contagion refers to crises spreading from one geographic region to another. In our context we use the term to indicate that a crisis in one policy field may also trigger a crisis in other policy fields. Like in the traditional interregional case also contagion from one policy field to the other may be caused by fundamental transmission channels and / or by changes in private expectations, which affect the policymakers' decision in other policy fields.
} 
acute in emerging markets and developing countries. ${ }^{5}$ Based on the experiences of the Latin American emerging market crises in the 1960s and 1970s the so-called first-generation currency crisis models (e.g. Krugman, 1979; Flood and Garber, 1984) focused on fundamental economic weaknesses such as excessive fiscal and monetary policies as major causes of the breakdown of fixed exchange rate regimes. Following the EMS crisis (1992-93) private devaluation expectations, which affect a government's policy decisions and thus can turn out to be self-fulfilling, became an important explanation of currency crashes in the socalled second-generation models (see e.g. Obstfeld, 1994; Obstfeld, 1996a; Ozkan and Sutherland, 1998). An central insight of this literature is that it is not a change in the market sentiment alone that drives financial crises. Economic fundamentals still play an important role. In situations with sufficiently good fundamentals the government is able and willing to defend the exchange rate peg irrespective of investors' expectations. In situations with very bad fundamentals it is the welfare maximizing option for the government to abandon the peg regardless of private expectations. Only in between these two extreme cases there is a zone with multiple equilibria, a "gray area" in terms of Obstfeld (1996b), where changes in private beliefs can lead to self-fulfilling currency crises. ${ }^{6}$

The literature on sovereign debt defaults has similar features. The level and maturity structure of debt are among the most important fundamental determinants of a government's decision to default on its debt service. In some situations default expectations of private investors may also trigger debt repudiation. If investors expect a (partial) default they demand higher interest rates to compensate for the default risk when they buy new bonds, thereby increasing the government's debt service obligations and thus its incentive to actually default. If, instead, investors do not expect a default and thus do not demand an extra risk default premium, the government is able and willing to service its debt. However, multiple equilibria with self-fulfilling private default expectations become possible only if economic fundamentals are sufficiently bad, e.g. if debt exceeds a crucial level. If debt is lower than this

\footnotetext{
${ }^{5}$ Rose (2002) and Rose and Spiegel (2002) illustrate that sovereign debt repudiation can cause a serious breakdown in international trade. Dooley (2000) among others finds that sovereign defaults are usually followed by major output losses. Currency crises typically also cause considerable economic setbacks. The IMF (1998) reports that from 1975 to 199761 percent of all currency crisis episodes were associated by a significant decline in GDP in terms of a negative deviation from trend output. In a sample of crises, which the IMF characterizes as particularly serious („currency crashes”), even 71 percent of the crises led to significant output losses. Based on a panel analysis of 24 emerging markets covering the time from 1975 to 1997, Hutchinson und Noy (2002) find that currency and balance-of-payments crises reduce real GDP by five to eight percent over a period of two to three years. However, currency crashes do not always cause a deep and long-lasting recession. For example following the Ruble crisis in 1998 Russia experienced positive GDP growth for the first time since the end of the Soviet Union. Growth was also accompanied by further positive developments, e.g. by a reduction of barter trade and by increased lending of the banking system to the private production (see Huang, Marin, and Xu, 2004). For a detailed description of the output effects during various crisis episodes see Gupta, Mishra, and Sahay (2003).

${ }^{6}$ For a comprehensive review on the first and second-generation currency crisis literature see Jeanne (2000).
} 
threshold, the government repays its debts even if default expectations cause the interest payments to rise. Cole and Kehoe (1998) show that lengthening the maturity increases this crucial level, i.e. with a longer maturity structure a higher debt level can be maintained without risking a financial crisis.

So far there exist only few theoretical studies on the simultaneous occurrence of sovereign debt and currency crises (see Obstfeld 1994, Jahjah and Montiel 2003, Herz 2005). In the following, we discuss several important links between debt and currency crises.

\section{Figure 1: Links between debt and currency crises}

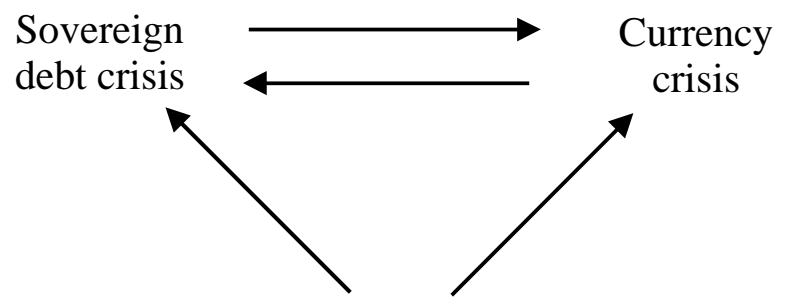

Common causes

Debt and currency crises can be positively correlated due to common causes and “internal contagion effects” between both types of crises. An example of a common cause is a negative shock to GDP growth, which reduces the government's tax base. As the public budget situation deteriorates, default becomes more likely. At the same time, a slowdown in GDP growth also raises the government's incentive to devalue in order to stimulate economic activity. Other important variables that can be interpreted in the sense of common causes are the volume, the currency structure, and the maturity structure of sovereign debt. These debt variables are all essential to determine the sustainability not only of the public debt burden but also of a country's balance of payments position.

There are also direct links between both kinds of crises (“internal contagion effects”). Devaluation can for example directly trigger a debt crisis as it increases the real value of foreign currency denominated debt ${ }^{7}$ or as it leads to credit rating downgrades, which increase the country's interest rate risk premium. ${ }^{8}$ The opposite causality, which runs from debt to currency crises, has already been stressed e.g. by the first-generation currency crisis models, which imply that excessive fiscal and debt policies can trigger speculative attacks.

\footnotetext{
${ }^{7}$ On the causes, implications, and possible cures of this so-called original sin phenomenon see Jeanne (2003), Eichengreen and Hausmann (2003), and Eichengreen, Hausmann, and Panizza (2002, 2003).

${ }^{8}$ See Calvo and Reinhart (2000) and Reinhart (2002) for empirical evidence and possible explanations of credit rating downgrades in the aftermath of devaluations.
} 
However, sovereign defaults and currency devaluations need not be linked positively. They can also be negatively correlated due to budget financing aspects. If a government faces a deficit and is neither able to increase its tax revenues nor to reduce its spending, it can choose among three other options of financing: (1) issuing new debt, thus raising both the overall debt burden and the risk of a future debt repudiation, (2) printing money, which induces inflation and currency pressure and thus increases the risk of a currency crisis, and (3) defaulting on debt coming due. From this perspective a government that finances its budget via a monetary expansion lowers the pressure to default and vice versa. ${ }^{9}$

Bauer, Herz, and Karb (2003) combine several of these factors into an integrated framework. Their approach includes the characteristic properties of the second generation currency crisis literature, but extends this framework to a government that - weighing the costs and benefits of its policy options - decides whether to abandon a fixed exchange rate peg and / or whether to default on its maturing debt service payments at the same time.

The sovereign policymaker is assumed to maximize welfare $W_{t}$

$$
W_{t}=Y_{t}-\lambda E_{t}-\eta F_{t}-c T_{t}
$$

$Y_{t}$ is real GDP. $\lambda$ and $\eta$ are dummy variables, which indicate the government's decision to devalue $(\lambda=1)$ or not to devalue $(\lambda=0)$ and to default $(\eta=1)$ or not to default $(\eta=0)$ on its debt service obligations. $E_{t}$ are the real costs of a devaluation, e.g. a loss of reputation. These costs depend in part on the devaluation rate, which reflects that interest rate premiums in affected countries typically rise in the aftermath of devaluations depending on the scale of devaluation. ${ }^{10}$ Devaluation, however, also yields some benefits for the government, e.g. surprise devaluation and the associated surprise inflation can increase GDP in terms of an expectations augmented Phillips curve. $F_{t}$ are the real costs of default, e.g. a loss of reputation, trade, and GDP. The term $c T_{t}$ denotes the costs of taxation, which are assumed to be a linear function of the government's real tax revenue $T_{t}$.

In maximizing public welfare the government is bound by its budget constraint. As long as the government honors its debt, expenditures on government consumption and debt service must be equal to tax revenues, new debt, and seigniorage. Under purchasing power parity the government's decision to devalue implies the decision to allow for inflation by an

\footnotetext{
${ }^{9}$ For a comprehensive overview over the theoretical and empirical links between currency and debt crises also see Herz and Tong (2003) and Dreher, Herz, and Karb (2004).

10 See Reinhart (2002) for empirical evidence that especially in emerging markets currency crises are often followed by credit rating downgrades.
} 
expansion of the monetary base and thus also determines the amount of seigniorage. The default expectations of private investors determine, at what price the government can finance its budget by selling new debt. With all other variables in the budget constraint set exogenously from the government's point of view, the amount of taxes which the government needs to collect to balance its budget and which negatively affect public welfare according to equation (1) depends on the government's decision whether to default and / or to devalue.

Bauer, Herz, and Karb (2003) show that as a result of the government's cost-benefitanalysis the decision to default and / or to devalue depends on both the level of public debt $B$ and monetary fundamentals $d$, with an increase in $d$ indicating deteriorating fundamentals. In some situations, the decision to devalue can also depend on the decision to default and vice versa. As a consequence, self-fulfilling private default expectations can in some situations cause not only debt crises but also currency crises. Figure 2 illustrates the government's optimal policy as a function of fiscal and monetary fundamentals. The policy choice is denoted as a vector $(\lambda / \eta)$.

Sectors labeled 1, 2, 3, and 4 in figure 2 show the combinations of debt levels $B$ and fundamentals $d$ for which the welfare maximizing policy does not depend on private expectations. In sector 1 with a low debt level and good monetary fundamentals, the optimal policy decision is to neither devalue nor to default ("no crisis": 0/0). In sector 2, where the monetary fundamentals are bad but the debt level is low, it is optimal to devalue only ("currency crisis": 1/0). In sector 3 with a high debt level and good monetary fundamentals the optimal policy is to default (“debt crisis”: 0/1). In sector 4 with high debt levels and bad fundamentals it is optimal to both devalue and to default ("twin debt and currency crisis": $1 / 1)$. 


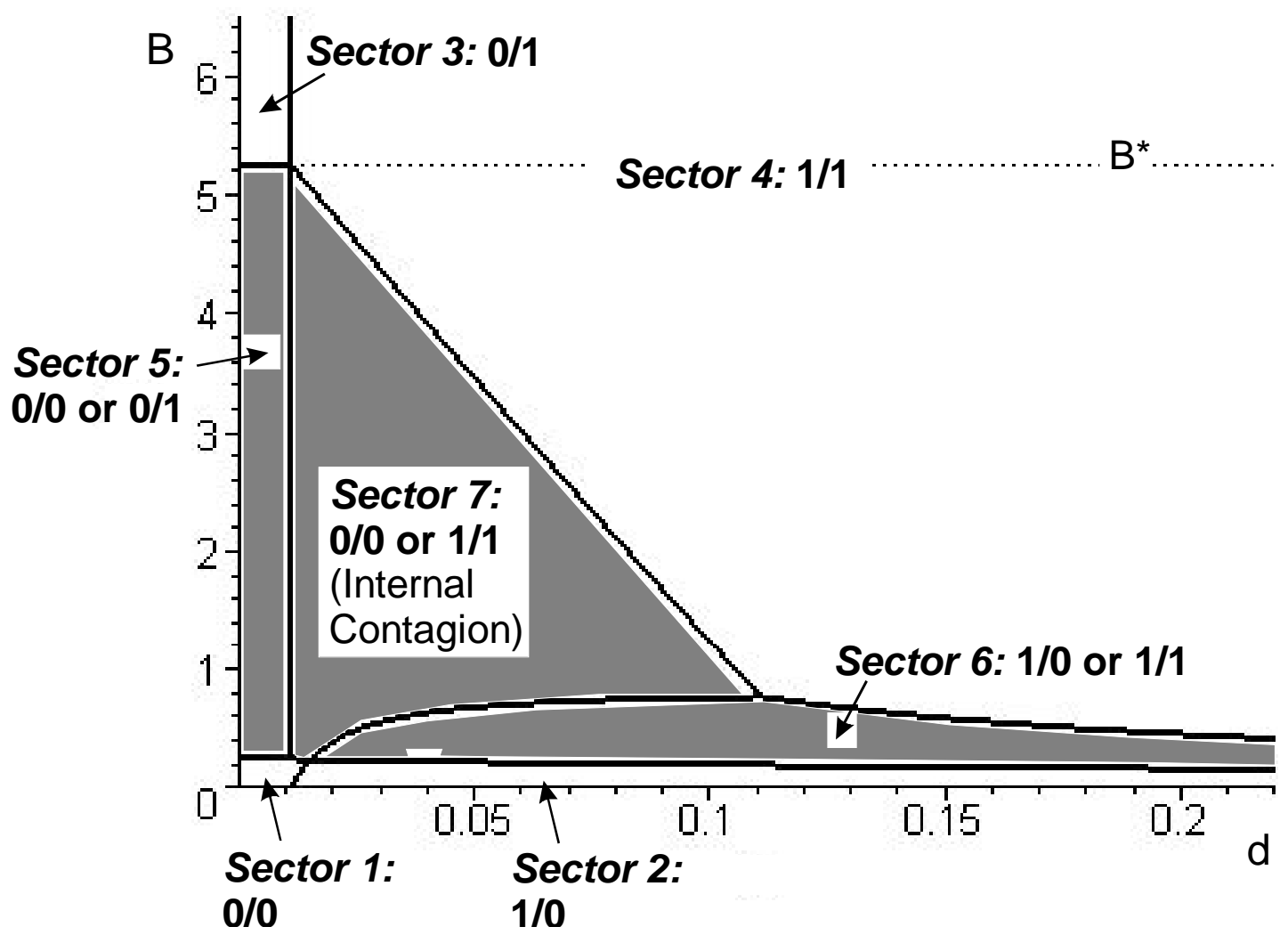

Figure 2: Optimal policies depending on the investors' default expectations.

In accordance with the second-generation currency crisis literature, in between these situations of unique equilibria there is a gray area of multiple equilibria, which is twodimensional in our case. In the sectors 5, 6, and 7 the investors' default expectations are selffulfilling, i.e. it is optimal for the government to default on its debt service obligations only if investors expect a default and to not default otherwise. In sector 5 , the fundamental economic situation is sufficiently good so that the government keeps the peg regardless of its debt policy and private expectations. In contrast, in sector 6 , the monetary fundamentals are sufficiently bad so that it is optimal for the government to devalue regardless of the debt policy. In sector 7 a situation of "internal contagion" arises. In these situations the debt policy also determines the exchange rate policy. If private investors expect a default, it is not only optimal for the government to actually default, but also to devalue. If, in contrast, investors do not expect a default, the government decides to not default and also to not devalue. 
Figure 2 indicates a kind of substitution effect of good monetary and fiscal fundamentals in preventing financial crises. The line, which separates sector 7 from sector 4 , indicates that - as long as the debt level is neither sufficiently high to trigger an inevitable debt crisis nor sufficiently low to eliminate any threat of a debt crisis - good monetary fundamentals do not only prevent currency crises but also help to avert expectations-based debt crises. In these situations any policy measure that improves the monetary fundamentals yields a double dividend as it helps to prevent both types of crises at the same time. Also, as long as the monetary fundamentals are neither good enough to avoid a currency crisis nor bad enough to trigger an inevitable currency crash, a low debt level does not only avert a debt crisis but also helps to fight off expectations-driven devaluations. In these situations a sound fiscal policy yields the same kind of double dividend. It helps to prevent both types of crises. $^{11}$

\section{Stylized facts}

\subsection{Causes and consequences of financial crises}

To give a first impression on the determinants of financial crises and their consequences we present the development of eight key economic variables before and after crisis situations and compare them to their average level in non-crisis situations. The variables are short-term debt (\% of total external debt), external debt (\% of GDP), net inflow foreign direct investment (\% of GDP), annual growth of GDP, inflation (log of annual change of consumer prices), overall budget balance including grants (\% of GDP), total reserves in months of imports, and overvaluation. ${ }^{12}$ The data are drawn from the World Bank World Development Indicators (WDI) 2004 data set. $^{13}$

Our benchmark sample includes 62 middle-income countries with an annual GDP between 766 and 9360 US Dollars and a population exceeding 1 million inhabitants. The sample covers the period from 1975 to $2002{ }^{14}$

\footnotetext{
${ }^{11}$ On the other hand, the substitution effect may also be interpreted in a negative way. If the debt level is sufficiently high, it may not only trigger a debt crisis, in addition it can cause a currency crisis, even if the monetary fundamentals are relatively good. Analogously, sufficiently bad monetary fundamentals may not only cause currency crises but can also lead to debt crises even in situations with relatively low debt levels.

${ }^{12}$ The official WDI terms are "Short-term debt (\% of total external debt)", "External debt, total (DOD, \% of GDP)", "Foreign direct investment, net inflows (\% of GDP)", "GDP growth (annual \%)", (logs of) "Inflation, consumer prices (annual \%)", "Overall budget balance, including grants (\% of GDP)", "Total reserves in months of imports". Overvaluation is defined as the deviation from the average US Dollar real exchange rate.

${ }^{13} \mathrm{http}: / /$ www.worldbank.org/data/wdi2004/index.htm.

${ }^{14}$ The definition of middle-income countries refers to the World Bank classification.
} 
The data on "debt crises" are adopted from Beers and Chambers (2002) who define debt crises as episodes, in which a debtor country unilaterally departs from the scheduled debt service, i.e. reschedules or ceases the debt service. The classification of "currency crises" corresponds to Frankel and Rose (1996) with a currency crisis being defined as a drop in the yearly mean of the US Dollar official exchange rate of more than 25 percent. Analogous to Glick and Hutchinson's (1999) twin banking and currency crisis definition, we characterize twin debt and currency crises as the simultaneous occurrence of a debt and a currency crisis in the same year. To account for endogeneity and simultaneity problems, we apply a symmetric seven-year window around crisis events, i.e. three years before and three years after a crisis are separately defined as pre- respectively post-crisis events (see e.g. Frankel and Rose 1996). ${ }^{15}$ These definitions leave us with a sample of 500 data points without a crisis, 59 pure currency crises, 65 pure debt crises, and 44 twin crises, as well as 610 pre- or post-crisis events.

Figures 3 and 4 visualize the behavior of the eight key macroeconomic variables in the years before and after crisis episodes. The " 0 " on the time line denotes the crisis year. ${ }^{16}$ The solid black lines in figure 3 and 4 depict the average behavior of the economic variable around a pure currency crisis. The dotted lines mark pure debt crises and the dash-dotted lines plot twin debt and currency crises. The horizontal line denotes the variables' averages in noncrisis periods.

Our data are likely to contain outliers as crises typically are caused and followed by extreme situations. To describe the average behavior of the macroeconomic variables around crises, we thus use a robust estimator for the mean. The $10 \%$ trimmed mean is robust and allows an intuitive understanding of how it handles the data. ${ }^{17}$

\footnotetext{
${ }^{15}$ Results of sensitivity analyses, e.g. on non-windowed data and alternative crises definitions, are reported in detail below.

${ }^{16}$ In the case of serial crisis episodes, i.e. if a country remains within a crisis situation for more than one year, the " 0 " in the figures 3 and 4 only indicates the first crisis year, i.e. the entry into a crisis. Alternatively we could use windows to account for repeated crises as in the graphical analysis by Frankel and Rose (1996). Such a classification would not change the results.

${ }^{17}$ The results do not change significantly for trim values between $5 \%$ and $35 \%$ or winsorizing with the same level. All estimations are performed with the S-Plus statistics program.
} 
Figure 3: Debt, FDI flows, and GDP growth before and after crises in middleincome countries (1975-2002).

Short-term debt (\% of total external debt)

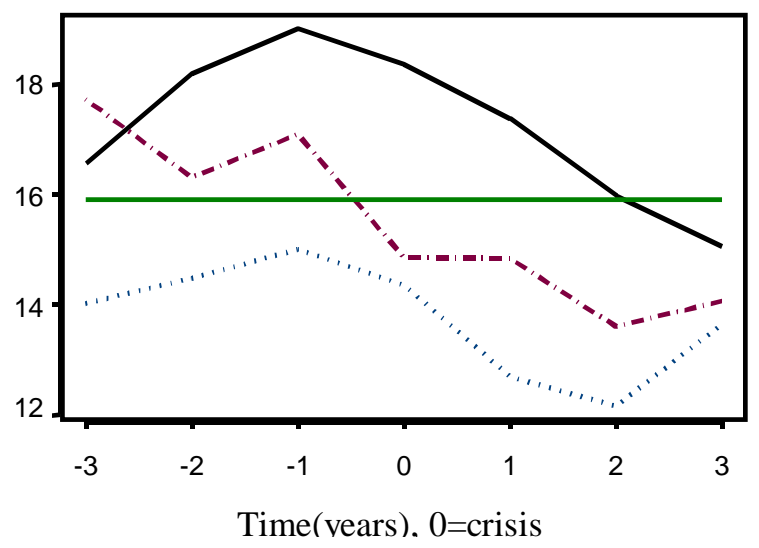

Foreign direct investment, net inflows (\% of GDP)

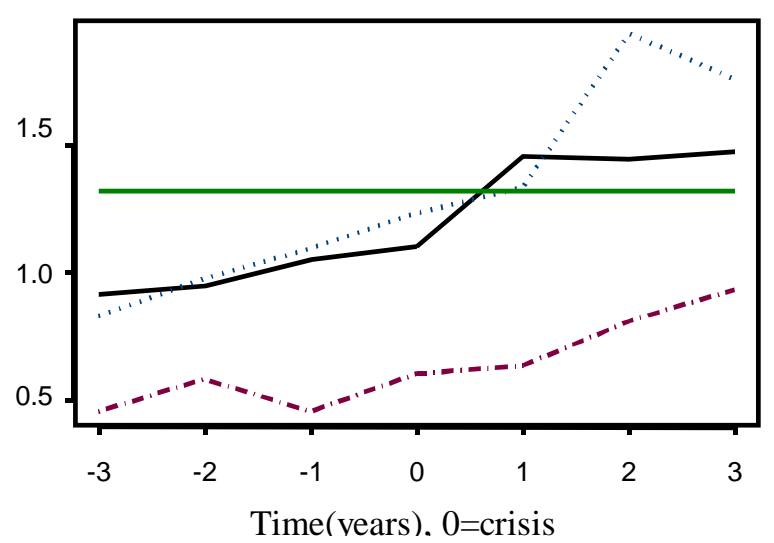

External debt, total (DOD, \% of GDP)

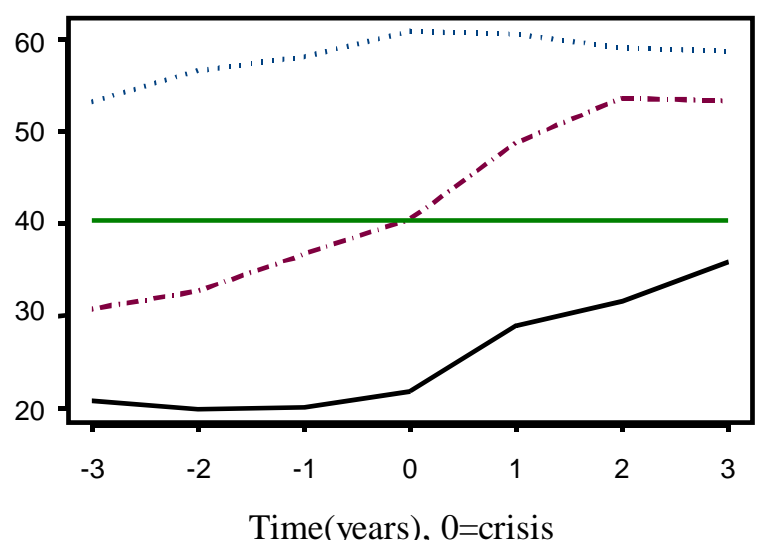

GDP growth (annual \%)

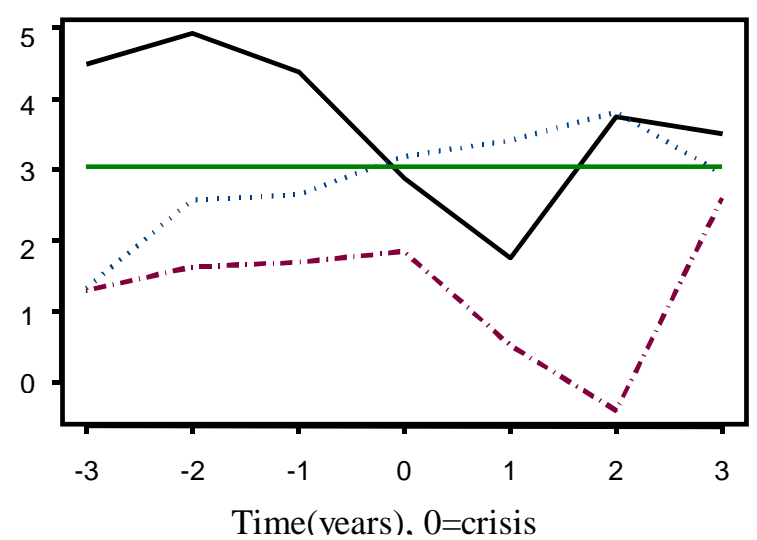

The visualizations already give a first impression of how twin crises differ from pure debt and currency crises. Figure 3 indicates that before a pure currency crisis short-term debt is higher than average and increasing, while the external debt level remains low. Pure currency crises seem to be linked to illiquidity as foreign reserves are drained to support the exchange rate and as the demand for reserves increases to raise the prolongation frequencies of debt. After pure currency crises the share of short-term debt declines, while total external debt increases. Above average external debt levels seem to be typical for countries with pure debt crises. The years after debt crises are characterized by a reduction of short-term debt, which might be due to debt rescheduling. For pure currency and twin crises external debt starts at lower than average levels and increases sharply during the crises. This finding could be related to the original sin phenomenon, i.e. if a high share of a country's debt is denominated in foreign currency, the real value of debt increases in the course of devaluation. 
GDP growth might serve as an indicator for pure currency crises, as it typically begins to decline from a high level in the year(s) before the crises and reaches its minimum level in the year after. While in the case of pure debt crises GDP growth seems to be unaffected by the crisis event, countries with twin crises have below-average growth rates throughout the depicted period and face their growth minimum two years after the crisis. Though twin crises exhibit the strongest drop in growth among all crisis types, the growth path recovers on average within three years after the crisis.

Foreign direct investment sharply increases after pure currency and pure debt crises. This could be related to the dissolution of uncertainty about the impending crisis or the assessment of international investors that inadequate policies, which led to the crises, are corrected. In the case of twin crises, however, FDI only slowly increases from a belowaverage level after the crisis. This may indicate that from a foreign investor's perspective twin crisis countries seem to have more severe problems, which are not significantly resolved during the crises.

Figure 4 shows that average inflation declines during and after pure debt crises, while it increases after currency crises. Twin crisis countries are characterized by above-average inflation, which further increases during and after the crises.

The upper right diagram in figure 4 depicts the overall budget balance around crisis situations. While budget deficits sharply decrease after pure debt crises (either due to debt rescheduling or better fiscal discipline), the situation in currency crises deteriorates continuously. Twin crises are preceded and followed by excessive budget deficits.

The reserves over imports ratio clearly differentiates between the three types of crisis. In pure debt crises reserves are lower than average, while they are above average for pure currency crises and drop in the crisis year, possibly due to an attempt to defend the currency. For twin crises the reserves over imports ratio stays around average. The relatively low level for debt crisis countries may originate from a group effect, namely that these countries tend to have floating exchange rate regimes and thus hold relatively little reserves. Finally, the lower right diagram in figure 4 shows that overvaluation is significantly reduced in the course of currency as well as twin crises, while no effect is visible for pure debt crises. ${ }^{18}$

\footnotetext{
${ }^{18}$ In part this may be due to the definition of real overvaluation as the difference of the current real exchange rate from its average. A large nominal devaluation and sticky prices in an otherwise undisturbed data series by definition imply that the real exchange rate is above average before and below average after a devaluation.
} 
Figure 4: Inflation, budget balance, reserves, and overvaluation before and after crises in middle-income countries (1975-2002).

Inflation, annual change of consumer prices (annual \%)

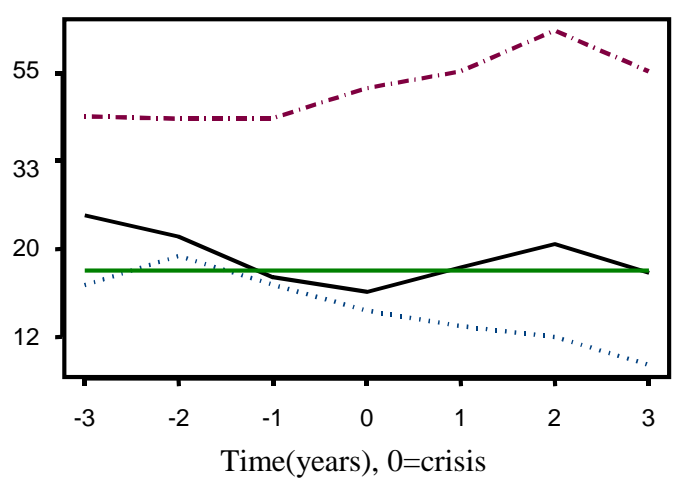

Total reserves in months of imports

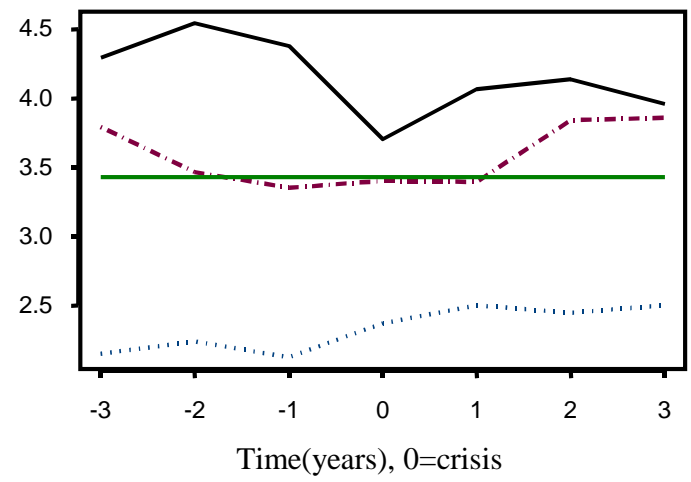

Overall budget balance, including grants (\% of GDP)

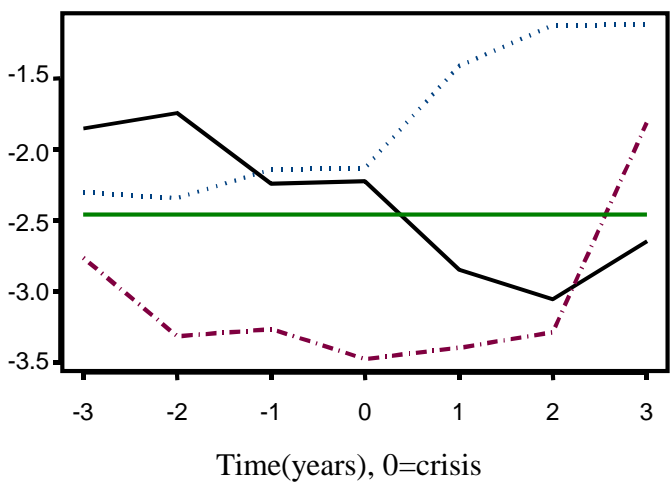

Overvaluation

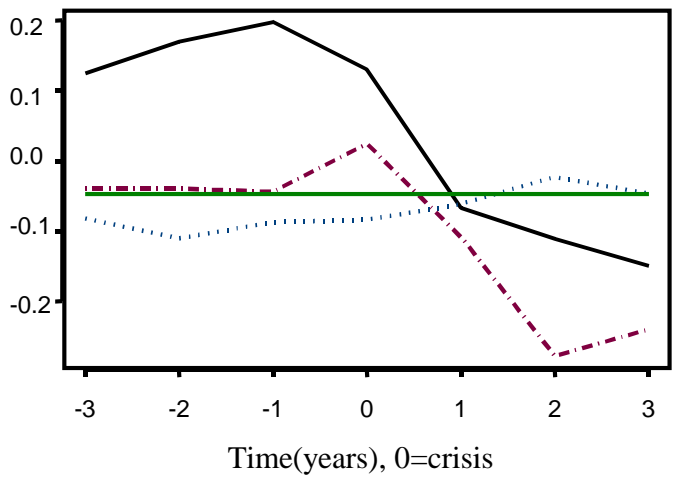

The intuitive appeal of these explanatory variables is tested by a Wilcoxon test. Table 2 in the appendix contains the results of the test. While figures 3 and 4 show the development of the variables throughout time, we can only compare the location of the different groups for a single point of time. We choose the year before the crisis events, as these data points are used below in the predictive model. In general, the test validates the results of the visual interpretation with the exception of rather strong results for the inflation variable and weak results for the budget balance variable.

\section{2. $\quad$ Fiscal and monetary fundamentals in crisis situations}

Debt and currency crises are typically regarded to be the consequence of bad monetary and fiscal fundamentals. Figures 5 and 6 plot the external debt level of the 62 middle-income countries in our sample as a proxy variable for the fiscal fundamentals and the M2 to foreign 
reserves ratio as a proxy variable for the monetary fundamentals. ${ }^{19} \mathrm{~A}$ rising M2 to reserves ratio indicates an increasing scale of liquidity in the financial system and thus deteriorating economic fundamentals in terms of the currency crisis literature, ${ }^{20}$ while an increasing level of external debt indicates deteriorating economic fundamentals in terms of the debt crisis literature.

\section{Figure 5: Distribution of macroeconomic fundamentals in crises episodes}

No crisis

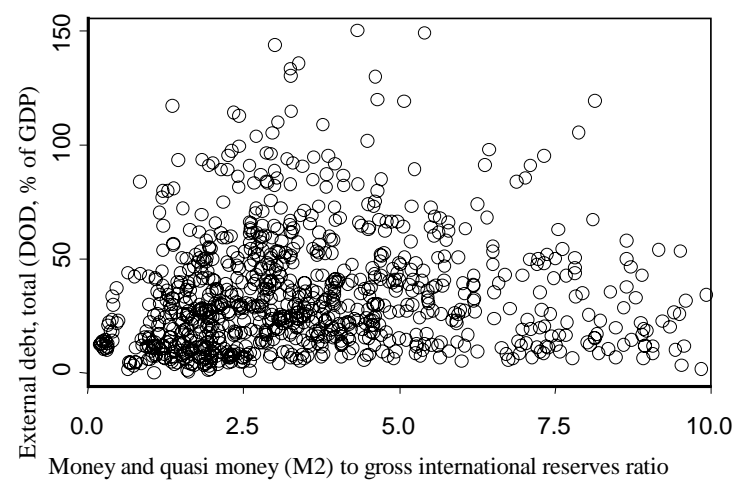

Pure debt crisis

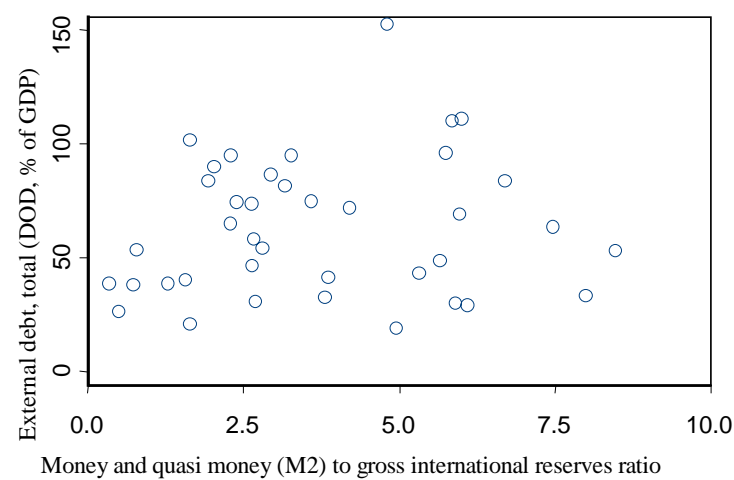

Pure currency crisis

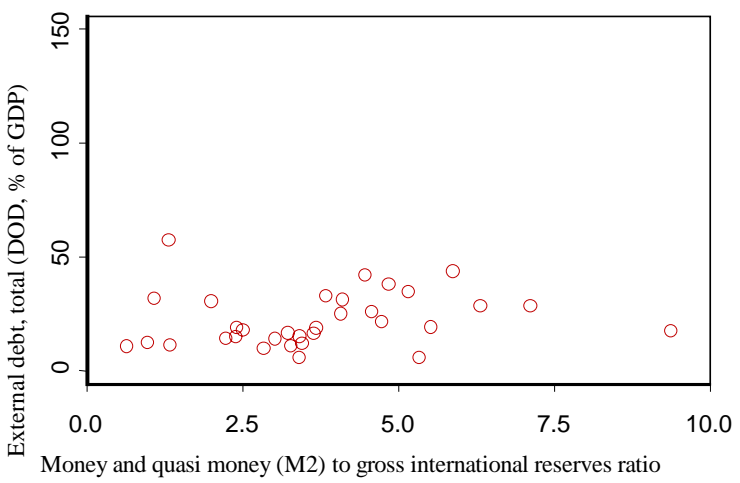

Twin crisis

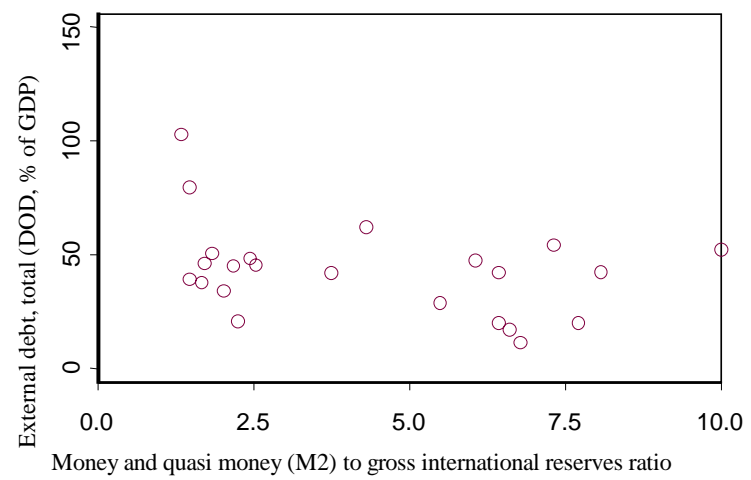

Figure 5 divides the sample into four subgroups, namely countries, which experienced "no crisis” (marked black in the following), “debt crises” (blue), “currency crises” (red), and "twin debt and currency crises” (purple). The annual data range from 1974 to 2002 so that each country appears at most 29 times in the figure. ${ }^{21}$

Figure 6 combines all episodes into one plot. The ellipses in figure 6 are minimal volume ellipsoid (MVE) estimates of the occurrences of the different types of crises. The

\footnotetext{
${ }^{19}$ Data are again drawn from World Bank’s World Development Indicators series. The debt variable refers to the World Bank's total external debt time series.

${ }^{20}$ See e.g. Calvo and Mendoza (1996), who point to a fatal M2 to foreign exchange reserves ratio as an important reason of the 1994-95 Mexican crisis.

${ }^{21}$ Countries with crises events appear less often in the graph, as pre and post crises episodes are omitted in the figure.
} 
centers of the ellipsoids are robust estimates of the bivariate average of the monetary and the debt variable in the case of debt, currency, or twin crisis, respectively. The edges of the ellipses indicate a distance of one multivariate standard deviation from the center of the respective groups.

Figure 6: Mean and dispersion of the indicator variables before and during crises

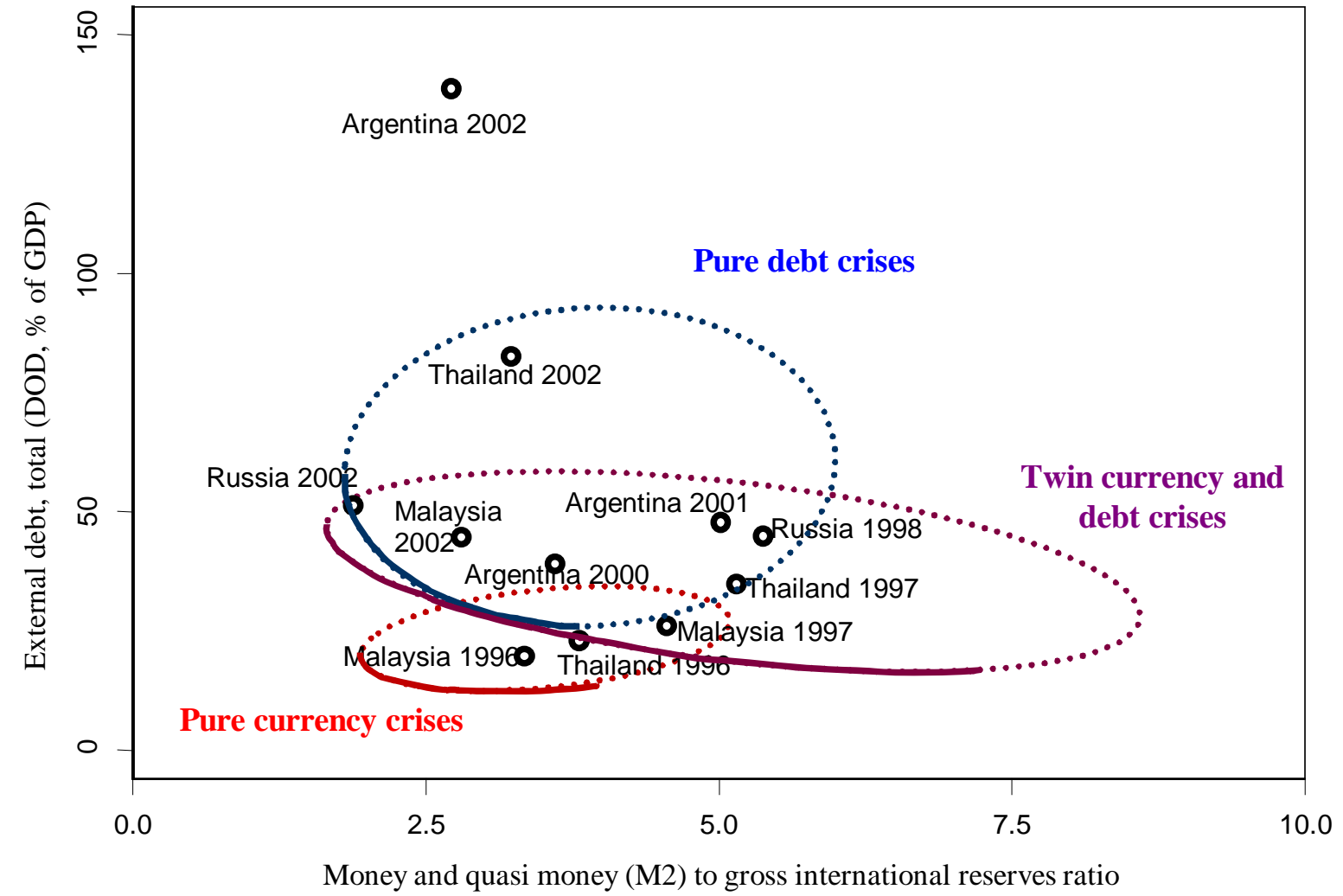

Selected data points of recent prominent crises are added to the plot of the crisis ellipsoids. For example Argentina moved from the southwest of the twin crisis ellipsoid in the year 2000 towards the northeast indicating a higher likelihood of a twin crisis, which in fact developed in the year 2001. The 2002 data in the north of the debt ellipse corresponds to the continuing debt crisis. Likewise the Russian Federation, which in the year 1998 was located in the center of the twin crisis ellipse, afterwards moved to the more stable western side of the twin crisis zone. Given the improvement in the year 2002 and Russia's subsequent early repayment of debts, Russia is likely to have left the crisis area. The macroeconomic fundamentals of Thailand and Malaysia deteriorated when they moved inside the twin crisis ellipse and faced a (twin banking and) currency crisis. Until the year 2002 their monetary fundamentals have improved again, while fiscal fundamentals have deteriorated particularly in Thailand. 
These stylized illustrations provide some interesting insights. It comes as no surprise, that non-crisis episodes are associated with good macroeconomic fundamentals, i.e. are concentrated in the lower left part of figure 5. Pure debt crisis episodes frequently occur, if the debt level is high while the monetary fundamentals are in good condition. The debt crisis ellipse in figure 6 indicates that the critical debt level seems to be around 40 percent of GDP. Pure currency crisis episodes frequently occur at low debt levels but weak monetary fundamentals. Twin debt and currency crises in general occur when fiscal as well as monetary fundamentals are bad.

The slightly negatively sloped twin crisis ellipse points to the kind of substitution effect between the fiscal and the monetary fundamentals, which was indicated in figure 2 . Very low debt levels may not only prevent debt crises but can also contribute to prevent currency crises. Analogously, very good monetary fundamentals may not only avert currency depreciations but can also help to avoid debt crises.

It is important to note, that the ellipses in figure 6 indicate a distance of one standard deviation from the bivariate average of the specific crisis episodes. Therefore, the intuition of the figure only is that countries placed below and / or left of the ellipses due to relatively low debt levels and / or relatively good monetary fundamentals are on average less frequently subject to crises than countries placed inside the ellipses. This does not mean, however, that countries outside the ellipses are immune to crises. The respective crises are only more frequent among countries within the ellipses than among countries outside. On the other hand, not all countries inside a crisis ellipse necessarily face a crisis. For example several countries suffered from debt crises even though their debt level was much lower than the 40 percent of GDP, which is suggested as critical by the debt crisis ellipse. ${ }^{22}$

Several of the "no crisis" episodes in figure 5 overlap with the debt and currency crisis ellipses in figure 6 . In this respect the figures 5 and 6 are also well in accordance with the prediction of figure 2 and the whole second generation currency crisis literature, that there exists a gray area where the optimal policy depends crucially on the private market participants' expectations. The dispersion of the data can be interpreted as an indication, that it is actually not the fundamental situation of a country alone that determines whether a financial crisis takes place. Shifts in private expectations play an important role as well. Medium debt levels and/or monetary fundamentals make a country vulnerable to financial crises in terms of self-fulfilling creditor panics. The situation is stable as long as there is no reversal in market sentiment. However, as soon as an external shock causes creditors to fear

\footnotetext{
${ }^{22}$ For a discussion of emerging markets' debt rescheduling and defaults at debt levels as low as 15 to 40 percent of GDP see Reinhart, Rogoff, and Savastano (2003) and Reinhart and Rogoff (2004).
} 
devaluation and / or default, rising interest rate risk premiums and inflation expectations make it more costly for the government to service its debt and / or to keep a peg. If these expectations-driven costs become prohibitively high, the government chooses to default and / or to devalue. Policy measures in this situation should therefore aim at the stabilization of private expectations.

An interesting question is how the combinations of debt to GDP ratios and M2 to reserves ratios above and right of the ellipses should be interpreted. Do worse fiscal fundamentals and / or worse monetary fundamentals indicate a diminishing risk of experiencing the respective type of crisis? In the case of the pure currency crisis and the pure debt crisis ellipses the answer can indeed be yes. Above and right of the debt and the currency crises ellipses the frequency (or the "risk") of pure currency crisis and pure debt crisis episodes actually decreases with deteriorating fundamentals simply because at the same time the frequency ("risk") of twin debt and currency crises increases. In the case of the twin crisis ellipse, however, the upper right edge of the ellipse simply defines the distance of one multivariate standard deviation from the average debt to GDP ratio and the M2 to reserves ratio in the sub-sample of combined debt and currency crises and indicates that there are only very few data points further outside in the deteriorating fundamentals area.

\section{Empirical analysis}

\subsection{GLM estimations}

In the following we develop a classification and an early warning system for the different types of crises. Like Frankel and Rose (1996) we use a number of macroeconomic variables to explain and predict crises within a generalized linear model (GLM) with a logit link function. In contrast to their approach, we do not restrict our analysis to currency crises but analyze all three types of crises: pure currency crises, pure debt crises, and twin debt and currency crises. Within the GLM-logit model we first use contemporary variables to explain the crisis occurrence. We then introduce lagged variables in a GLM-logit estimation to constitute an early warning system. Our macroeconomic dataset is used to predict the probability of a currency, debt, or twin crisis in the following year. The explanatory models perform slightly better than the predictive ones. Both types of models, explanatory and predictive, show similar results in comparison to the traditional estimations. Thus, we only present the results for the predictive models in this section and leave the results of the explanatory model to the appendix. 
The macroeconomic explanatory variables, which for the most part have already been discussed in the previous section, are external debt (\% of GDP), M2 over reserves, short-term debt (\% of external debt), net inflow foreign direct investment (\% of GDP), real GDP annual growth, overall budget balance including grants (\% of GDP), interest rate spread (lending rate minus deposit rate), total reserves in months of imports, annual consumer price inflation, total expenditure (\% of GDP), and overvaluation. ${ }^{23}$

In total we present five estimations for the explanatory and the predictive case, which differ with respect to the definition of the dependent variable. In each regression the dependent variable is binomial. The first three estimates cover pure currency, pure debt, and twin crises. For example in the first regression on pure currency crises, " 1 ” is assigned to each case with a currency crisis, while " 0 " is assigned to all other cases, i.e. pure debt crises, twin crises, and non-crisis situations.

To compare our approach to the conventional results, the last two estimations are based on the traditional method to only distinguish between currency and debt crises and to not consider twin currency and debt crises as a separate type of crisis. Instead, in the fourth estimation each case in which a currency crisis occurs, i.e. both pure currency crises and twin crises, is marked " 1 ”. Analogously, in our last regression every situation in which a debt crisis occurs, i.e. both pure debt crises and twin crises, is marked " 1 ".

Table 3: Crisis definitions for the regressions

\begin{tabular}{|l|l|l|}
\hline & Type of crisis & Explanation \\
\hline 1 & Pure currency crisis & Currency crisis, no debt crisis \\
\hline 2 & Pure debt crisis & Debt crisis, no currency crisis \\
\hline 3 & Twin crisis & Simultaneous currency and debt crisis \\
\hline 4 & All currency crises & Pure currency and twin crises \\
\hline 5 & All debt crises & Pure debt and twin crises \\
\hline
\end{tabular}

The regression equations

$$
I\left(y^{j}\right)=\sum_{i=1}^{11} \theta_{i}^{j} x
$$

\footnotetext{
${ }^{23}$ The data is again drawn from the World Bank World Development Indicators (WDI) 2004 data set.
} 
connect the eleven independent macroeconomic variables with the probability of the occurrence of the dependent variable $y^{j}, \mathrm{j}=1 . .5$, indicating the five types of crises as defined in table 3. For the link function l, we choose the logit function.24

When we compare our approach, i.e. treating twin crises as a separate type of crisis, to the traditional approach, our main findings concern (a) the predictability of crises, (b) internal contagion effects, and (c) selection bias effects. We furthermore find that there are specific macroeconomic explanations for each single type of crisis.

(a) With respect to the predictability of crises, the differentiated analysis of each type of crisis significantly improves the predictability of pure debt and twin crises but not the predictability of pure currency crises. The predictability of twin crises is the best among all crisis types. More than half of the twin crises in the sample can be predicted with only a negligible number of false alarms.

(b) With respect to internal contagion effects, we find that the maturity structure, i.e. the share of short-term debt, seems to be a significant factor in traditional empirical studies of debt crises only because it is relevant for twin crises. While it is not relevant for pure debt crises, it has a rather strong impact only on twin crises as it promotes currency crises, which can trigger debt crises via contagion. This impact influences estimations of mixed pure debt and twin crisis samples.

(c) We also encounter pre-selection bias effects. Foreign exchange reserves for example have a significant negative influence on the probability of pure debt crises, but a positive influence on currency and twin crises, i.e. pure debt crises are associated with comparatively low reserve ratios, while twin crises are connected with comparatively high reserve ratios. This finding can be due to a pre-selection bias with regard to the exchange rate system: A need for high reserve ratios typically arises only in countries with fixed exchange rate regimes. Fixed exchange rate regimes are, however, more likely subject to a speculative attack than floating exchange systems. Thus in countries with high reserve ratios (i.e. fixed exchange rate regimes) debt crises are more likely to be associated with simultaneous currency crises than in countries with low reserve ratios (i.e. flexible exchange rates).

\footnotetext{
${ }^{24}$ Other links, like the probit function, either don't represent the model structure appropriately or don't yield significantly different results.
} 
In the following we discuss the specific macroeconomic determinants for the different types of crisis in greater detail and highlight how treating twin crises as a separate type of crisis can deepen our understanding of different financial crises.

\subsection{Macroeconomic crisis indicators}

As it is standard in the literature, we interpret significant coefficients from our estimations as relevant for the explanation and accordingly for the prediction of the respective type of crisis. Insignificant estimates are perceived as irrelevant. Table 4 combines the results of our five separate GLM-logit regressions of the predictive models. The complete tabulation of the regression results can be found in section 6.3 of the appendix. Significant results correspond to p-values below 5\%.

Table 4: Estimated coefficients of the predictive crisis models

\begin{tabular}{|c|c|c|c|c|c|}
\hline & $\begin{array}{c}\text { Pure } \\
\text { currency } \\
\text { crises }\end{array}$ & $\begin{array}{c}\text { Currency } \\
\text { crises } \\
\text { including } \\
\text { twin crises }\end{array}$ & $\begin{array}{l}\text { Pure debt } \\
\text { crises }\end{array}$ & $\begin{array}{l}\text { Debt crises } \\
\text { including } \\
\text { twin crises }\end{array}$ & Twin crises \\
\hline Intercept & $-4.42 * *$ & $-5.34 * * *$ & $-11.19 * * *$ & $-13.65 * * *$ & $-14.68 * * *$ \\
\hline External debt, total & -0.45 & -0.36 & $3.09 * * *$ & $3.41 * * *$ & 0.91 \\
\hline $\begin{array}{l}\text { Money and quasi money (M2) to gross } \\
\text { international reserves ratio }\end{array}$ & $1.15 * * *$ & $1.46 * * *$ & 0.02 & $0.70 *$ & $1.75^{* *}$ \\
\hline Short-term debt & 0.00 & 0.01 & 0.03 & $0.07 * *$ & $0.11 * *$ \\
\hline Foreign direct investment & -0.13 & -0.19 & $-0.32 * *$ & $-0.38 * *$ & -0.11 \\
\hline Real GDP growth & $0.10 *$ & 0.08 & 0.10 & 0.09 & 0.05 \\
\hline Overall budget balance & 0.05 & 0.02 & -0.05 & -0.13 & -0.29 \\
\hline Interest rate spread & 0.00 & 0.04 & 0.00 & 0.02 & 0.00 \\
\hline Total reserves in months of imports & 0.10 & 0.15 & $-0.38 * *$ & $-0.26 *$ & 0.24 \\
\hline Inflation & $0.62 * *$ & $0.80 * * *$ & $0.43 * *$ & $0.67 * * *$ & $1.66^{* *}$ \\
\hline Total expenditure & 0.00 & -0.02 & $-0.10 * * *$ & $-0.14 * * *$ & $-0.14 * *$ \\
\hline Overvaluation & $1.53 * *$ & $1.17 * *$ & $1.42 *$ & $1.77 * *$ & 0.50 \\
\hline Ratio of explained de & 0.18 & 0.27 & 0.40 & 0.47 & 0.47 \\
\hline
\end{tabular}

Bold: Significant at the $1 \%$ level $(* * *)$, the $5 \%$ level $(* *)$, or the $10 \%$ level $(*)$.

\section{Currency crises:}

Significant factors for the prediction of currency crises are the money to GDP ratio, inflation, and overvaluation. This finding holds for pure currency crises as well as for the combination of pure currency and twin crises. Most of these results are well known from the literature on currency crises (e.g. Frankel and Rose, 1996; Dreher, Herz, and Karb, 2004). A high monetary base, high inflation rates, and overvaluation typically indicate a high likelihood of an impending currency crisis. 
The impact of GDP growth on the probability of pure currency crises is weakly but significantly positive while it is insignificant for the joined currency and twin crises sample, i.e. higher growth seems to raise the risk of pure currency crises, but not the risk of currency crises in general. This result, which might be surprising at first sight, becomes clear if the separation of pure currency and twin crises is taken into account. A country with weak monetary fundamentals (high monetary base, high inflation) and strong real fundamentals (high real GDP growth) is likely to resolve its problems solely within the monetary sector, i.e. with a pure currency crisis. In contrast, countries with bad monetary fundamentals and low real growth are more likely to be subject not only to a currency crisis but also to an additional debt crisis. Thus in a sub-sample of countries with bad monetary fundamentals countries with low real growth are more likely to experience twin crises than pure currency crises. From a reverse respective this implies that higher growth can make the occurrence of pure currency crises more likely because it makes twin crises less likely.

\section{Debt crises:}

Three factors significantly raise the probability of debt crises in both the pure debt crises and the debt and twin crises sample. These are the external debt over GDP ratio, inflation and overvaluation. Higher FDI, reserves over imports and expenditures over GDP ratios lower the probabilities.

The difference between specifications that do and do not treat twin crises as a separate type of crisis is even more important in the analysis of debt crises than in the case of currency crises. There is a significant positive influence of the share of short-term debt and the monetary aggregate M2 on debt crises only in the mixed "debt or twin crisis" sample but not in the "pure debt crisis" sample. The significant positive effect of these monetary variables on the crisis probability in the mixed "debt or twin crisis" sample seems to be only due to its influence in the twin crises sample. This means that a high level of M2 to GDP or a shorter maturity of external debt does not raise the probability of debt crises as such. Instead, it increases the probability of a currency crisis in a first step, which may then trigger a simultaneous debt crisis via contagion effects. The estimation using the traditional crisis definition indicates that a shorter maturity structures increases the risk of a debt crisis. This result is commonly interpreted as supporting the illiquidity argumentation of sovereign debt crises. Our results show that the illiquidity argumentation is likely to be more relevant in case of twin currency and debt crises. This may be due to the fact that foreign reserves can be used only once: either to support the exchange rate or to repay foreign debt. 
The negative influence of reserves on the probability of debt crises could be due to a selection bias. The effect of reserves over imports is different for pure debt and twin crises. Higher reserves lower the probability of pure debt crises and raise the probability of twin crises. The difference between pure debt and twin crises is the occurrence of a currency crisis simultaneously to the debt crisis. A currency crisis typically occurs in managed exchange rate regimes when market pressure builds up and the target rate cannot be defended anymore, so that an abrupt and strong devaluation takes place. In order to manage the exchange rate in the first place, however, a certain amount of reserves is necessary. Thus, countries without reserves cannot manage their exchange rates and are rarely subject to a currency crisis according to our definition. This interpretation is also supported by further estimation results. The coefficients for reserves over imports are positive, albeit not significant, in the pure currency, the currency and twin, and the twin crisis model. The coefficient is highest in the twin crisis model.

\section{Twin crises:}

High money to GDP ratios, high shares of short-term debt, and inflation all raise the probability of twin crises. A high budget balance (i.e. a low deficit) and a high expenditure to GDP ratio lower it. The significance and sign of most of these variables are as expected from the debt and currency crisis literature. Fiscal deficits significantly raise the probability of twin crises but not the probability of pure currency or pure debt crises. Furthermore, although overvaluation significantly raises the probability of pure currency as well as pure debt crises, it does not significantly influence the probability of twin crises.

\section{Sensitivity analysis}

We checked the sensitivity of the results in two directions. Firstly, we tested for effects of alternative window sizes around crisis events and for variations of crisis definitions. Variations of the window size between one and five years do not affect our results. Omission of the window procedure increases the number or crises considerably, yet hardly changes the empirical results. Exceptions are FDI, which becomes significant for currency crises, as well as the budget balance and reserves over imports, which are significant in the case of twin crises. The signs of the coefficients (significant or insignificant) remain unchanged.

In contrast, it would have a major impact to reverse the order of the windowing procedure and the twin crisis definition, i.e. to first apply a window to the currency and debt crises and to afterwards look for twin crises in the remaining sample, as it would cut down the 
number of twin crises in our sample to eight. However, such order does not appear to be reasonable, as e.g. a three-year currency crisis, which is accompanied by a debt crisis in the second year, should be treated as a twin crisis event.

Secondly, we used the model selection procedure "step.glm" to account for possible identification problems due to correlations of the exogenous variables. Most of the correlations remain rather low. Only five of the 55 correlation coefficients have an absolute value higher than 0.3. We find strong negative correlations between external debt and shortterm debt, external debt and overvaluation, and between money and the reserves over imports. We also find high positive correlations between the interest rate spread and inflation as well as between the overall budget balance and the reserves over imports ratio. The latter correlation appears to be responsible for the low significance of the budget balance variable in the full twin crisis model. The optimal models as judged by the AIC criterion account for some of these correlations. These models include the significant variables as given in table 4 and in addition the external debt variable for all models and the overvaluation variable also for the twin crisis model. The signs of the coefficients remain unchanged. ${ }^{25}$

\subsection{Crisis predictions}

The GLM-logit regressions of the previous section are based on windowed data to avoid endogeneity or simultaneity problems for the interpretation of the results. However, omitting these data points also means neglecting valuable information. We now compare the predictive power of early warning systems using our crises definitions with systems using traditional definitions. The endogeneity problem in the interpretation can be neglected, as we are interested only in the predictive power of the models. We include the pre and post crisis data into all models to get the optimal predictions results.

\section{Twin crises}

Twin crises are easier to predict than any other type of crisis. We use a cutoff value of 0.3 for the GLM probability estimate to define the crisis prediction and obtain the following results. $^{26}$

\footnotetext{
${ }^{25}$ In the reduced model the negative coefficient of the external debt variable in the pure currency crises model and the currency and twin crises model is significant. It separates currency from twin crises. A country, which faces a currency crises, is likely to enter a pure currency crisis if external debt is low, and it is likely to enter a twin currency and debt crisis if the level of external debt is high.

${ }^{26}$ Obviously, a higher threshold results in a lower number of alarms, i.e. a smaller number of false alarms as well as a smaller number of correct warnings. We use a common threshold for the estimations of all three types of crises in order to reduce the number of free variables and to increase the tractability of the analysis. The threshold of 0.3 results in a reasonable average number of false alarms. Raising this value would not drastically reduce the number of false alarms in the currency crisis model but it would reduce its efficiency. Lowering the
} 
Table 5: Contingency table for the prediction of twin crises as a unique type of crisis

\begin{tabular}{|l|l|c|c|c|c|}
\cline { 3 - 6 } \multicolumn{2}{c|}{} & \multicolumn{5}{c|}{ True incidence } \\
\cline { 2 - 6 } \multicolumn{2}{c|}{} & Non-crisis & Pure currency crisis & Pure debt crises & Twin crisis \\
\hline $\begin{array}{l}\text { Predicted } \\
\text { incidence }\end{array}$ & Non-crisis & 363 & 38 & 111 & 14 \\
\cline { 2 - 6 } & Twin crisis & 1 & 3 & 8 & 15 \\
\hline
\end{tabular}

Over half of the twin crises (15 out of 29) are predicted correctly. In eleven cases a twin crisis was predicted but turned out to remain a pure currency crisis (8) or a pure debt crisis (3). In only one of the non-crisis situations (0.3\%) the model predicts a twin crisis, i.e. the number of false alarms is negligible. In 502 cases (363 non-crises, 38 pure currency crises, 111 pure debt crises) the model correctly predicts, that no twin crisis will occur.

As a comparison we provide the results of the estimations with the traditional crisis definitions. For this purpose we combine the results of the GLM estimations on all currency and all debt crises. A twin crisis is predicted if a debt and a currency crisis are indicated at the same time. To allow the comparability of the two approaches, the cutoff values are adjusted to match the number of false alarms in table 5.

Table 6: Contingency table for the prediction of twin crises with traditional crisis definition

\begin{tabular}{|l|c|c|c|c|c|}
\cline { 3 - 6 } \multicolumn{2}{c|}{} & \multicolumn{4}{c|}{ True incidence } \\
\cline { 3 - 6 } \multicolumn{2}{c|}{} & Non-crisis & Pure currency crisis & Pure debt crises & Twin crisis \\
\hline $\begin{array}{l}\text { Predicted } \\
\text { incidence }\end{array}$ & Non-crisis & 363 & 34 & 117 & 20 \\
\cline { 2 - 6 } & Twin crisis & 1 & 7 & 2 & 9 \\
\hline
\end{tabular}

The traditional approach predicts twin crises less exactly than our approach, which treats twin crises as a separate type of crisis. With the same number of false alarms (one alarm in 364 non-crises situations) our approach correctly predicts 15 out of 29 twin crises (52\%), while the traditional approach reaches only nine out of 29 (31\%). A binomial test that compares the number of correct predictions in both approaches shows that the number of correct predictions is significantly higher in our approach (p-value of $0.6 \%$, using the traditional crisis definition

threshold would increase the number of false alarms in the debt crisis model (12\%) to inefficient levels. The relative results, however, don't hinge on the threshold value. The prediction using the different crisis definitions, which is new in our approach, is always superior to the prediction using the traditional definitions. 
as null hypothesis) and significantly smaller in the traditional approach (p-value of $2 \%$, using our crisis definition as null hypothesis).

\section{Predictability of debt and currency crises}

The explanation and prediction of currency crises within macroeconomic early warning systems has been an extensive but hardly successful field of research. A number of different approaches with various sets of variables, e.g. Frankel and Rose (1996), Bussiere and Fratzscher (2002), or Komulainen and Lukkarila (2003), do not find convincing and corresponding results for the hypothesis that macroeconomic variables might serve as reliable predictors of currency crises.

With regard to debt crises, the literature also finds little evidence that macroeconomic variables are suitable for the construction of early warning systems (see IMF 2002). Our empirical results indicate that the performance of early warning systems can be improved if twin crises are treated as a separate crisis type. In contrast, the predictive power of early warning system is significantly worse if debt crises are defined in the traditional way, i.e. including both pure debt crises and twin debt and currency crises.

\section{Currency crises}

In order to analyze our early warning system we again set the cutoff value for the GLM probability estimation to 0.3 and use the current values of the explanatory variables to predict the probability of a crisis in the following year. A currency crisis is predicted if either the pure currency crisis predictor or the twin crisis predictor exceeds the threshold. The results are tabulated in table 7.

Table 7: Contingency table for the prediction of currency crises with twin crises as a unique type of crisis

\begin{tabular}{|l|l|c|c|c|}
\hline & & \multicolumn{3}{|c|}{ True incidence } \\
\hline & & $\begin{array}{c}\text { Non- } \\
\text { crisis }\end{array}$ & $\begin{array}{c}\text { Pure currency } \\
\text { or twin crisis }\end{array}$ & Pure debt crises \\
\hline $\begin{array}{l}\text { Predicted } \\
\text { incidence }\end{array}$ & Non-crisis & 358 & 45 & 110 \\
\cline { 2 - 5 } & Currency or twin crisis & 6 & 25 & 9 \\
\hline
\end{tabular}

Only 36\% of the currency crises are predicted correctly (25 out of 70). However, the number of false alarms is also very low. In nine cases with a predicted currency crisis (a pure currency or a twin crisis) a pure debt crisis occurred. The ratio of false alarms is only $1.6 \%$. 
As a comparison we provide the results of the GLM estimation with the traditional currency crisis definition including pure currency crises and twin crises. To allow the comparability of the two approaches, in table 8 the cutoff value is adjusted to match the number of false alarms in table 7.

Table 8: Contingency table for the prediction of currency crises with the traditional crisis definition

\begin{tabular}{|l|l|c|c|c|}
\hline & & \multicolumn{3}{|c|}{ True incidence } \\
\hline & & $\begin{array}{c}\text { Non- } \\
\text { crisis }\end{array}$ & $\begin{array}{c}\text { Pure currency } \\
\text { or twin crisis }\end{array}$ & Pure debt crises \\
\hline $\begin{array}{l}\text { Predicted } \\
\text { incidence }\end{array}$ & Non-crisis & 358 & 49 & 112 \\
\cline { 2 - 5 } & Currency or twin crisis & 6 & 21 & 7 \\
\hline
\end{tabular}

Although the overall performance of the new approach is not entirely satisfactory, it still works better than the conventional approach. Both hit rates - 25 out of 70 correct currency crisis predictions in our approach and 21 out of 70 in the traditional approach - do not differ significantly. The binomial tests, which compare the hit ratios, yield p-values of $12 \%$ and $19 \%{ }^{27}$

The performance of both approaches is nevertheless considerably better than the results of Frankel and Rose (1996), who predict only 5 out of 69 currency crises correctly. This improvement might be due to either the choice of the explanatory variables or - more likely - to the choice of the countries at stage. Our sample of emerging countries might be more homogenous with respect to the causes of financial crises than the larger Frankel and Rose (1996) sample.

\section{Debt crises}

Debt crises are defined as an alarm signal by the pure debt crisis or the twin crisis predictor. Again current values of the variables are used to predict the probability of a crisis in the following year with a threshold of 0.3 for the GLM probability estimates. The results are shown in table 9.

Table 9: Contingency table for the prediction of debt crises with twin crises as a unique type of crisis

\section{True incidence}

\footnotetext{
${ }^{27}$ For the explanatory model our approach performs weakly but significantly better (p-value of 5.7\%). The results are shown in the appendix.
} 


\begin{tabular}{|l|l|c|c|c|}
\hline & Non-crisis & $\begin{array}{c}\text { Pure debt or } \\
\text { twin crisis }\end{array}$ & $\begin{array}{c}\text { Pure currency } \\
\text { crises }\end{array}$ \\
\hline $\begin{array}{l}\text { Predicted } \\
\text { incidence }\end{array}$ & Non-crisis & 319 & 38 & 33 \\
\cline { 2 - 5 } & Debt or twin crisis & 45 & 110 & 8 \\
\hline
\end{tabular}

The result is rather convincing. The model predicts almost three quarters of all debt crises (110 out of $148,74 \%)$. However, the ratio of false alarms is rather high (12\%). ${ }^{28}$ The results from the GLM estimation with the traditional debt crisis definition, i.e. including pure debt crises and twin crises, are given in table 10 as a reference. To allow the comparability of the two approaches, the cutoff value is adjusted to match the number of false alarms in table 9.

Table 10: Contingency table for the prediction of debt crises with traditional crisis definition

\begin{tabular}{|l|l|c|c|c|}
\hline & & \multicolumn{3}{|c|}{ True incidence } \\
\hline & & Non-crisis & $\begin{array}{c}\text { Pure debt or } \\
\text { twin crisis }\end{array}$ & $\begin{array}{c}\text { Pure currency } \\
\text { crises }\end{array}$ \\
\hline $\begin{array}{l}\text { Predicted } \\
\text { incidence }\end{array}$ & Non-crisis & 317 & 97 & 21 \\
\cline { 2 - 5 } & Debt or twin crisis & 47 & 51 & 20 \\
\hline
\end{tabular}

The traditional approach predicts only 34\% of all debt crises correctly (51 out of 148). With a hit ratio of $74 \%$ our approach of treating twin crises as a separate type of crisis thus also yields distinctly better results with regard to the prediction of debt crises. A comparison of the number of correct predictions in both approaches with a binomial test shows that the number of correct predictions is in fact significantly higher in our approach (taking the traditional crisis definition as null hypothesis) and significantly lower in the traditional approach (taking our crisis definition as null hypothesis). The p-values of both tests are numerically 0 . Our results lead to the conclusion, that an early warning system for debt crises can successfully be based on macroeconomic variables. However, such a warning system can be successful if and only if twin crises are treated as a separate type of crisis.

\section{Conclusions}

\footnotetext{
${ }^{28}$ The number of false alarms would be smaller with a higher threshold. For example a threshold of 0.5 for the debt crisis model results in only eleven false alarms but also reduces the ratio of correct warnings to 54\%. See footnote 22 for a motivation of our choice.
} 
Our theoretical and empirical evidence strongly suggests to regard twin debt and currency crises as a specific type of crisis, which should be analyzed separately from pure currency and pure debt crises. Such a classification helps to better understand the interrelations between fiscal and exchange rate crises. Each of the three types of crises - pure currency, pure debt and twin debt and currency crises - is characterized by a unique set of causes and consequences. Theory suggests a number of possible interrelations between debt and currency crises, which include common causes, contagion effects from one crisis to the other, and complementary budget financing aspects.

Recapitulating the results of our GLM estimations this new approach to treat twin crises as a distinct type of crisis also significantly improves the predictive power of early warning systems. Our model predicts $36 \%$ of all currency crises, $75 \%$ of all debt crises, and $50 \%$ of all twin crises correctly, while we only get $1.6 \%$ false alarms for the prediction of currency crises, $12 \%$ false alarms in the case of debt crises, and $0.3 \%$ false alarms for currency crises. With these results our approach performs significantly better than traditional early warning systems on currency and debt crises which typically do not differentiate between pure currency crises (or pure debt crises respectively) and twin crises.

As major reasons for the inferior performance of the traditional approach, we identify internal contagion and selection bias effects, which may lead to biased results if twin crises are not treated separately. While for example in traditional empirical analyses short-term debt is often found to be a significant predictor for debt crises, we show that in fact it has no significant influence on the risk of pure debt crises. It rather increases the probability of currency crises, which then can trigger debt crises via contagion effects. Short-term debt thus seems to be an important explanatory variable in traditional debt crisis samples only because of its relevance for twin crises, which is carried forward to the entire sample. The example of the foreign exchange reserves shows how selection bias effects affect the predictive value of empirical analyses. Reserves have a significant negative influence on the probability of pure debt crises, but a positive influence on twin crises, i.e. pure debt crises are associated with comparatively low reserve ratios, while twin crises are connected with comparatively high reserve ratios. A possible explanation for this result is that high reserve ratios are less important under floating exchange rates than in fixed exchange rate systems. As countries with fixed exchange rates are more likely to become subject to speculative attacks and currency crises in terms of our crisis definition, debt crises are more likely to be associated by simultaneous currency crises in countries with high reserve ratios (i.e. fixed exchange rate regimes) than in countries with low reserve ratios (i.e. flexible exchange rates). We also find 
that growth seems to raise the probability of pure currency crises, while it does not significantly influence the crisis risk in the combined currency and twin crises sample. A possible explanation for this finding is that countries with weak monetary but strong real fundamentals are likely to be able to confine crises to the monetary sector. Countries with weak monetary fundamentals are in general likely to encounter currency crises, but they are likely to experience a simultaneous debt crisis as well only if growth is low. Thus with higher growth rates the probability of pure currency crises declines simply as the probability of twin crises increases.

The differentiation between currency, debt, and twin currency and debt crises improves the performance of early warning systems based on macroeconomic indicators and helps to better identify key variables explaining the economic intuition behind these crises. Thus the definition of crisis events appears to be fundamental for this kind of analysis. 


\section{Literature:}

Bauer, Christian, Bernhard Herz and Volker Karb (2003), The Other Twins: Currency and Debt Crises“, Review of Economics, 54 (3): 248-267.

Bordo, Michael D. and Barry Eichengreen, (2003), Crises Now and Then: What Lessons from the Last Era of Financial Globalization?, in: Mizen, Paul (edt.), Monetary History, Exchange Rates and Financial Markets. Essays in Honour of Charles Goodhart, Cheltenham and Northampton: 52-91.

Bordo, Michael D., Barry Eichengreen, Daniela Klingebiel, and Martinez-Peria, Maria S. (2001), Is the Crisis Problem Growing More Severe?, Economic Policy, 16 (32): 51-82.

Bussiere, Matthieu and Fratzscher, Marcel (2002), Towards a New Early Warning System of Financial Crises, European Central Bank, Working Paper No. 145.

Calvo, Guillermo A. and Mendoza, Enrique G. (1996), Mexico’s Balance-of-Payments Crisis: A Chronicle of a Death Foretold, Journal of International Economics, 41 (3-4): 235-264.

Calvo, Guillermo A. and Carmen M. Reinhart (2000), Fixing for Your Life, NBER Working Paper No. 8006.

Cantor, Richard and Frank Packer (1996), Determinants and Impact of Sovereign Credit Ratings, Federal Reserve Bank of New York, Economic Policy Review, October: 37-53.

Cole, Harold L. and Timothy J. Kehoe (1998), Self-Fulfilling Debt Crises, Federal Reserve Bank of Minneapolis Research Department Staff Report 211.

De Largy, P. J. R. and Goodhart, Charles (1999), Financial Crises: Plus ça change, plus c'est la meme chose, LSE Financial Markets Group Special Paper No. 108.

De Nicolo, Gianni, Sami Geadah and Dimitiy Rozhkov (2003), Financial Development in the CIS-7 Countries: Bridging the Great Divide, IMF Working Paper No. 03-205.

Dooley, Michael P. (2000), Can Output Losses Following International Financial Crises be Avoided?, NBER Working Paper No. 7531.

Dreher, Axel, Bernhard Herz, and Volker Karb (2004), Is There a Causal Link between Currency and Debt Crises?, University of Bayreuth, Discussion Papers in Economics No. 03-04.

Edison, Hali J. (2003), Do Indicators of Financial Crises Work? An Evaluation of an Early Warning System, International Journal of Finance and Economics, 8(1): 11-53.

Eichengreen, Barry (2002), International Financial Crises: Is the Problem Growing?, in: Jahrbuch für Wirtschaftsgeschichte, 2000(1): 89-104.

Eichengreen, Barry, Ricardo Hausmann and Ugo Panizza (2002), Original Sin: The Pain, the Mystery, and the Road to Redemption, Paper prepared for the conference "Currency and 
Maturity Matchmaking: Redeeming Debt from Original Sin”, Inter-American Development Bank, Washington D.C., 21-22 November 2002.

Eichengreen, Barry, Ricardo Hausmann and Ugo Panizza (2003), The Pain of Original Sin, mimeo, http://emlab.berkeley.edu/users/eichengr/research/ospainaug21-03.pdf.

Eichengreen, Barry and Ricardo Hausmann (2003), Original Sin: The Road to Redemption, mimeo, http://emlab.berkeley.edu/users/eichengr/research/osroadaug21-03.pdf.

Flood, Robert P. and Peter M. Garber, (1984), Collapsing Exchange-Rate Regimes: Some Linear Examples, Journal of International Economics, 17: 1-13.

Frankel, Jeffrey A. and Andrew K. Rose (1996), Currency Crashes in Emerging Markets: An Empirical Treatment, Journal of International Economics, 41 (3-4): 351-366.

Glick, Reuven and Michael Hutchison (1999), Banking and Currency Crises: How Common Are Twins?, Federal Reserve Bank of San Francisco, Center for Pacific Basin Monetary and Economic Studies, Working Paper No. PB 99-07.

Gros, Daniel (2003), Who Needs Foreign Banks?, Center for Economic Studies \& Ifo Institute for Economic Research (CESifo), Working Paper No. 998.

Gupta, Poonam, Deepak Mishra and Ratna Sahay (2003), Output Response to Currency Crisis, IMF Working Paper No. 03/230.

Herz, Bernhard and Hui Tong (2003), The Interactions between Debt and Currency Crises Common Causes or Contagion?, University of Bayreuth, Discussion Papers in Economics No. 17-03.

Herz, Bernhard (2005), The Logic of Twin Debt and Currency Crises, Kredit und Kapital 38/1, 1-21.

Huang, Haizhou, Dalia Marin and Chenggang Xu (2004), Financial Crisis, Economic Recovery, and Banking Development in Russia, Ukraine and Other FSU Countries, IMF Working Paper No. 04-105.

Hutchinson, Michael M. and Ilan Noy (2002), Output Costs of Currency and Balance of Payments Crises in Emerging Markets, Comparative Economic Studies, 44 (2/3): 27-44.

Lai, Alexandra (2002), Modeling Financial Instability: A Survey of the Literature, Bank of Canada, Working Paper No. 2002-12.

IMF - International Monetary Fund (1998), Financial Crises: Causes and Indicators, World Economic and Financial Surveys, World Economic Outlook, May.

IMF - International Monetary Fund (2002), Global Financial Stability Report, A Quarterly Report on Market Developments and Issues, March. 
Jahjah, Samir and Peter Montiel (2003), Exchange Rate Policy and Debt Crises in Emerging Economies, IMF Working Paper 03/60, Washington D.C.

Jacobs, Jan, Gerard H. Kuper and Lestano (2004), Currency Crises in Asia: A Multivariate Logit Approach, University of Groningen, Department of Economics, http://www.eco.rug.nl/ kuper/download/factansignextrcc.pdf.

Jeanne, Olivier (2000), Currency Crises: A Perspective on Recent Theoretical Developments, Princeton University, International Finance Section, Special Papers in International Economics No. 20.

Jeanne, Olivier (2003), Why Do Emerging Market Economies Borrow in Foreign Currency?, IMF Working Paper No. 03-177.

Kaminsky, Graciela and Carmen Reinhart (1999), The Twin Crises: The Causes of Banking and Balance-of-Payments-Crises, in: American Economic Review, 89(3): 568-592.

Keller, Peter M. and Thomas Richardson (2003), Nominal Anchors in the CIS, IMF Working Paper No. 03-179.

Komulainen, Tuomas and Lukkarila, Johanna (2003), What Drives Financial Crises in Emerging Markets?, Bank of Finland Institute for Economies in Transition (BOFIT), Discussion Paper No. 05/2003.

Kruger, Mark, Patrick N. Osakwe and Jennifer Page (1998), Fundamentals, Contagion, and Currency Crises: An Empirical Analysis, Bank of Canada Working Paper No. 98/10, Ottawa.

Krugman, Paul R. (1979), A Model of Balance-of-Payments Crises, Journal of Money, Credit and Banking, 11(3): 311-325.

Krugman, Paul R. (1996), Are Currency Crises Self-Fulfilling?, in: NBER Macroeconomics Annual, ed. by B. S. Bernanke and J. J. Rotemberg, Cambridge and London: 345-378.

Obstfeld, Maurice (1994), The Logic of Currency Crisis, Banque de France, Cahiers economiques et monetaires, 43: 189-213.

Obstfeld, Maurice (1996a), Models of Currency Crises with Self-Fulfilling Features, European Economic Review, 40: 1037-1047.

Obstfeld, Maurice (1996b), Comment, in: NBER Macroeconomics Annual, ed. by B. S. Bernanke and J. J. Rotemberg, Cambridge and London: 393-403.

Ozkan, Gulzin F. and Alan Sutherland (1998), A Currency Crisis Model with an Optimising Policy Maker, Journal of International Economics, 44: 339-364.

Reinhart, Carmen M. (2002), Default, Currency Crises and Sovereign Credit Ratings, NBER Working Paper No. 8738. 
Rose, Andrew K. (2002), One Reason Countries Pay Their Debts: Renegotiation and International Trade, NBER Working Paper No. 8853.

Rose, Andrew K. and Mark M., Spiegel (2002), A Gravity Model of Sovereign Lending: Trade, Default and Credit, NBER Working Paper No. 9285.

\section{Appendix}

Table 2:Results of the Wilcoxon test for location: p-values

\begin{tabular}{|l|l|l|l|l|l|l|l|l|l|}
\hline $\begin{array}{l}\text { Crises } \\
\text { types }\end{array}$ & $\begin{array}{l}\text { Short- } \\
\text { term } \\
\text { debt }\end{array}$ & $\begin{array}{l}\text { External } \\
\text { debt }\end{array}$ & FDI & $\begin{array}{l}\text { GDP } \\
\text { growth }\end{array}$ & $\begin{array}{l}\text { Inflatio } \\
n\end{array}$ & $\begin{array}{l}\text { Budget } \\
\text { balance }\end{array}$ & $\begin{array}{l}\text { Reserve } \\
\text { s }\end{array}$ & $\begin{array}{l}\text { Over- } \\
\text { valuatio } \\
\text { n }\end{array}$ & M2 \\
\hline NC-CC & 0.01 & 1.00 & 1.00 & 0.80 & 0.00 & 0.28 & 0.22 & 0.00 & 0.01 \\
\hline NC -DC & 0.43 & 0.00 & 1.00 & 1.00 & 0.00 & 0.15 & 1.00 & 0.96 & 0.00 \\
\hline NC -TC & 0.05 & 0.04 & 1.00 & 1.00 & 0.00 & 0.91 & 0.99 & 0.25 & 0.00 \\
\hline CC -DC & 0.98 & 0.00 & 0.64 & 0.94 & 0.62 & 0.42 & 1.00 & 1.00 & 0.08 \\
\hline NC -TC & 0.60 & 0.00 & 0.99 & 0.99 & 0.00 & 0.92 & 0.98 & 0.99 & 0.06 \\
\hline DC-TC & 0.10 & 1.00 & 0.96 & 0.92 & 0.00 & 0.97 & 0.02 & 0.19 & 0.44 \\
\hline
\end{tabular}

The full names of the variable are "Short-term debt (\% of total external debt)", "External debt, total (DOD, \% of GDP)”, “Foreign direct investment, net inflows (\% of GDP)”, “GDP growth (annual \%)”, ”Inflation, GDP deflator (annual \%)”, “Overall budget balance, including grants (\% of GDP)”, “Total reserves in months of imports”, “Overvaluation”, and "Money and quasi money (M2) to gross international reserves ratio".

The columns give the results for the alternative variables. The rows compare different pairs of crisis types. We use „NC” for “no crisis”, “CC” for “pure currency crisis”, “DC” for “pure debt crisis", and "TC" for "twin crisis". We test the null hypothesis of equal means against the alternative that the mean of the first crisis type is lower than for the second crises type. The pvalues for alternative "higher" is given by simply subtracting the tabulated result from unity, i.e. the p-value "0.98” in cell "CC-DC, Short-term debt" is to be interpreted in the following way: The null hypothesis of equal location is rejected with p-value 1-0.98 $=2 \%$ against the alternative that the average Short term debt one year before the crisis is higher in pure currency crises than in pure debt crises.

\subsection{Results of the explanatory model}

The explanatory model uses contemporary values of the macroeconomic variables to analyze the determinants of the different types of crises. 
Table 11:

Contingency table for the explanation of twin crises as a unique type of crisis

\begin{tabular}{|l|l|c|c|c|c|}
\hline & & \multicolumn{4}{|c|}{ True incidence } \\
\hline & $\begin{array}{c}\text { Non- } \\
\text { crisis }\end{array}$ & $\begin{array}{c}\text { Pure currency } \\
\text { crisis }\end{array}$ & $\begin{array}{c}\text { Pure debt } \\
\text { crises }\end{array}$ & Twin crisis \\
\hline Predicted incidence & Non-crisis & 351 & 41 & 122 & 14 \\
\cline { 2 - 6 } & Twin crisis & 3 & 5 & 5 & 16 \\
\hline
\end{tabular}

Table 12:

Contingency table for the explanation of twin crises with traditional crisis definition

\begin{tabular}{|l|l|c|c|c|c|}
\hline & \multicolumn{5}{|c|}{ True incidence } \\
\hline & $\begin{array}{c}\text { Non- } \\
\text { crisis }\end{array}$ & $\begin{array}{c}\text { Pure currency } \\
\text { crisis }\end{array}$ & $\begin{array}{c}\text { Pure debt } \\
\text { crises }\end{array}$ & $\begin{array}{c}\text { Twin } \\
\text { crisis }\end{array}$ \\
\hline Predicted incidence & Non-crisis & 351 & 39 & 121 & 20 \\
\cline { 2 - 6 } & Twin crisis & 3 & 7 & 6 & 10 \\
\hline
\end{tabular}

Table 13:

Contingency table for the explanation of currency crises with twin crises as a unique type of crisis

\begin{tabular}{|l|l|c|c|c|}
\hline & & \multicolumn{3}{|l|}{ True incidence } \\
\hline & & Non-crisis & $\begin{array}{c}\text { Pure currency } \\
\text { or twin crisis }\end{array}$ & $\begin{array}{c}\text { Pure debt } \\
\text { crises }\end{array}$ \\
\hline $\begin{array}{l}\text { Predicted } \\
\text { incidence }\end{array}$ & Non-crisis & 347 & 46 & 121 \\
\cline { 2 - 5 } & Currency or twin crisis & 7 & 30 & 6 \\
\hline
\end{tabular}

Table 14:

Contingency table for the explanation of currency crises with traditional crisis definition

\begin{tabular}{|l|l|c|c|c|}
\hline & & \multicolumn{3}{|c|}{ True incidence } \\
\hline & & Non-crisis & $\begin{array}{c}\text { Pure currency } \\
\text { or twin crisis }\end{array}$ & $\begin{array}{c}\text { Pure debt } \\
\text { crises }\end{array}$ \\
\hline \multirow{2}{*}{$\begin{array}{l}\text { Predicted } \\
\text { incidence }\end{array}$} & Non-crisis & 347 & 52 & 121 \\
\cline { 2 - 5 } & Currency or twin crisis & 7 & 24 & 6 \\
\hline
\end{tabular}

Table 15:

Contingency table for the explanation of debt crises with twin crises as a unique type of crisis

\begin{tabular}{|l|l|c|c|c|}
\hline & & \multicolumn{3}{|c|}{ True incidence } \\
\hline & & Non-crisis & $\begin{array}{c}\text { Pure debt or } \\
\text { twin crisis }\end{array}$ & $\begin{array}{c}\text { Pure currency } \\
\text { crises }\end{array}$ \\
\hline \multirow{2}{*}{$\begin{array}{l}\text { Predicted } \\
\text { incidence }\end{array}$} & Non-crisis & 314 & 40 & 32 \\
\cline { 2 - 5 } & Debt or twin crisis & 40 & 117 & 14 \\
\hline
\end{tabular}

Table 16:

Contingency table for the explanation of currency crises with traditional crisis definition 


\begin{tabular}{|l|l|c|c|c|}
\hline & Non-crisis & $\begin{array}{c}\text { Pure debt or } \\
\text { twin crisis }\end{array}$ & $\begin{array}{c}\text { Pure currency } \\
\text { crises }\end{array}$ \\
\hline $\begin{array}{l}\text { Predicted } \\
\text { incidence }\end{array}$ & Non-crisis & 313 & 98 & 20 \\
\cline { 2 - 5 } & Debt or twin crisis & 41 & 59 & 26 \\
\hline
\end{tabular}

\subsection{Estimated coefficients of the predictive model}

The predictive model uses the values of the macroeconomic variables one year prior to the crises to find predictors for the different crises types.

Table 17:

Estimated coefficients of the predictive pure currency crisis model

\begin{tabular}{|c|c|c|c|c|}
\hline & Value & Std. Error & t value & $\operatorname{Pr}(>|\mathbf{t}|)$ \\
\hline Intercept & -4.42 & 1.91 & -2.32 & 0.021 \\
\hline External debt, total (dod, \% of GDP) & -0.45 & 0.34 & -1.33 & 0.183 \\
\hline Money and quasi money (M2) to gross international reserves ratio & 1.15 & 0.41 & 2.84 & 0.005 \\
\hline Short-term debt (\% of total external debt) & 0.00 & 0.02 & 0.01 & 0.993 \\
\hline Foreign direct investment, net inflows (\% of GDP) & -0.13 & 0.12 & -1.08 & 0.282 \\
\hline GDP growth (annual \%) & 0.10 & 0.06 & 1.63 & 0.105 \\
\hline Overall budget balance, including grants (\% of GDP) & 0.05 & 0.07 & 0.82 & 0.413 \\
\hline Interest rate spread (lending rate minus deposit rate) & 0.00 & 0.00 & -0.71 & 0.480 \\
\hline Total reserves in months of imports & 0.10 & 0.10 & 1.05 & 0.295 \\
\hline Log of inflation, GDP deflator (annual \%) & 0.62 & 0.30 & 2.10 & 0.037 \\
\hline Expenditure, total (\% of GDP) & 0.00 & 0.02 & 0.01 & 0.994 \\
\hline Overvaluation & 1.53 & 0.60 & 2.55 & 0.011 \\
\hline
\end{tabular}

Table 18:

Estimated coefficients of the predictive pure debt crisis model

\begin{tabular}{l|cccc} 
& Value & Std. Error & $\mathbf{t}$ value & $\operatorname{Pr}(>|\mathbf{t}|)$ \\
\hline Intercept & $\mathbf{- 1 1 . 1 9}$ & 2.62 & -4.27 & 0.000 \\
External debt, total (dod, \% of GDP) & $\mathbf{3 . 0 9}$ & 0.61 & 5.09 & 0.000 \\
Money and quasi money (M2) to gross international reserves ratio & 0.02 & 0.39 & 0.05 & 0.963 \\
Short-term debt (\% of total external debt) & 0.03 & 0.03 & 1.16 & 0.246 \\
Foreign direct investment, net inflows (\% of GDP) & $\mathbf{- 0 . 3 2}$ & 0.15 & -2.20 & 0.029 \\
GDP growth (annual \%) & 0.10 & 0.07 & 1.50 & 0.135 \\
Overall budget balance, including grants (\% of GDP) & -0.05 & 0.08 & -0.64 & 0.523 \\
Interest rate spread (lending rate minus deposit rate) & 0.00 & 0.00 & -0.81 & 0.418 \\
Total reserves in months of imports & $\mathbf{- 0 . 3 8}$ & 0.16 & -2.41 & 0.017 \\
Log of inflation, GDP deflator (annual \%) & 0.43 & 0.22 & 1.98 & 0.049 \\
Expenditure, total (\% of GDP) & $\mathbf{- 0 . 1 0}$ & 0.03 & -3.33 & 0.001 \\
Overvaluation & $\mathbf{1 . 4 2}$ & 0.82 & 1.73 & 0.085
\end{tabular}


Table 19:

Estimated coefficients of the predictive twin crisis model

\begin{tabular}{l|cccc} 
& Value & Std. Error & $\mathbf{t}$ value & $\operatorname{Pr}(>|\mathbf{t}|)$ \\
\hline Intercept & $\mathbf{- 1 4 . 6 9}$ & 5.02 & -2.92 & 0.004 \\
External debt, total (dod, \% of GDP) & 0.91 & 0.88 & 1.03 & 0.302 \\
Money and quasi money (M2) to gross international reserves ratio & $\mathbf{1 . 7 5}$ & 0.69 & 2.54 & 0.012 \\
Short-term debt (\% of total external debt) & 0.11 & 0.05 & 2.14 & 0.033 \\
Foreign direct investment, net inflows (\% of GDP) & -0.11 & 0.32 & -.0 .33 & 0.740 \\
GDP growth (annual \%) & 0.05 & 0.11 & 0.42 & 0.675 \\
Overall budget balance, including grants (\% of GDP) & $\mathbf{- 0 . 2 9}$ & 0.17 & -1.70 & 0.09 \\
Interest rate spread (lending rate minus deposit rate) & 0.00 & 0.02 & -0.02 & 0.987 \\
Total reserves in months of imports & $\mathbf{0 . 2 4}$ & 0.25 & 0.96 & 0.336 \\
Log of inflation, GDP deflator (annual \%) & $\mathbf{1 . 6 6}$ & 0.73 & 2.29 & 0.023 \\
Expenditure, total (\% of GDP) & $\mathbf{- 0 . 1 4}$ & 0.06 & -2.14 & 0.033 \\
Overvaluation & 0.51 & 0.95 & 0.53 & 0.595
\end{tabular}

Table 20:

Estimated coefficients of the predictive currency crisis model including twin crises

\begin{tabular}{l|cccc} 
& Value & Std. Error & $\mathbf{t}$ value & $\operatorname{Pr}(>|\mathbf{t}|)$ \\
\hline Intercept & $-\mathbf{5 . 3 4}$ & 1.94 & -2.75 & 0.006 \\
External debt, total (dod, \% of GDP) & -0.36 & 0.34 & -1.05 & 0.296 \\
Money and quasi money (M2) to gross international reserves ratio & $\mathbf{1 . 4 6}$ & 0.40 & 3.63 & 0.000 \\
Short-term debt (\% of total external debt) & 0.01 & 0.02 & 0.56 & 0.575 \\
Foreign direct investment, net inflows (\% of GDP) & $\mathbf{- 0 . 1 9}$ & 0.12 & -.1 .53 & 0.127 \\
GDP growth (annual \%) & 0.08 & 0.06 & 1.51 & 0.133 \\
Overall budget balance, including grants (\% of GDP) & 0.02 & 0.07 & 0.31 & 0.753 \\
Interest rate spread (lending rate minus deposit rate) & 0.04 & 0.02 & 1.61 & 0.108 \\
Total reserves in months of imports & $\mathbf{0 . 1 5}$ & 0.10 & 1.55 & 0.123 \\
Log of inflation, GDP deflator (annual \%) & $\mathbf{0 . 8 0}$ & 0.28 & 2.84 & 0.005 \\
Expenditure, total (\% of GDP) & $\mathbf{- 0 . 0 2}$ & 0.02 & -1.08 & 0.282 \\
Overvaluation & $\mathbf{1 . 1 7}$ & 0.57 & 2.05 & 0.041
\end{tabular}

Table 21:

Estimated coefficients of the predictive debt crisis model including twin crises

\begin{tabular}{l|cccc} 
& Value & Std. Error & $\mathbf{t}$ value & $\operatorname{Pr}(>|\mathbf{t}|)$ \\
\hline Intercept & $\mathbf{1 3 . 6 5}$ & 2.86 & -4.77 & 0.000 \\
External debt, total (dod, \% of GDP) & $\mathbf{3 . 4 1}$ & 0.63 & 5.40 & 0.000 \\
Money and quasi money (M2) to gross international reserves ratio & 0.70 & 0.42 & 1.66 & 0.099 \\
Short-term debt (\% of total external debt) & 0.07 & 0.03 & 2.43 & 0.016 \\
Foreign direct investment, net inflows (\% of GDP) & $\mathbf{- 0 . 3 8}$ & 0.16 & -2.42 & 0.016 \\
GDP growth (annual \%) & 0.09 & 0.07 & 1.33 & 0.186 \\
Overall budget balance, including grants (\% of GDP) & -0.13 & 0.08 & -1.54 & 0.124 \\
Interest rate spread (lending rate minus deposit rate) & 0.02 & 0.03 & 0.66 & 0.508 \\
Total reserves in months of imports & -0.26 & 0.14 & -1.77 & 0.075 \\
Log of inflation, GDP deflator (annual \%) & $\mathbf{0 . 6 7}$ & 0.25 & 2.65 & 0.009 \\
Expenditure, total (\% of GDP) & $\mathbf{- 0 . 1 4}$ & 0.03 & -4.29 & 0.000 \\
Overvaluation & $\mathbf{1 . 7 7}$ & 0.88 & 2.02 & 0.044
\end{tabular}

